School of Finance

University of St.Gallen

THe EXPOSURe OF MORTgage BorRoWers to INTEREST RATE RISK, INCOME RISK AND HOUSE PRICE RISK - EVIDENCE FROM SWISS LOAN APPLICATION DATA

MARTIN BROWN

BENJAMIN GUIN

WORKING PAPER ON FINANCE NO. 2015/9

SWISS INSTITUTE OF BANKING AND FINANCE (S/BF - HSG)

THIS DRAFT: DECEMBER 2014 


\title{
The Exposure of Mortgage Borrowers to Interest Rate Risk, Income Risk and House Price Risk - Evidence from Swiss Loan Application Data
}

\author{
MARTIN BROWN* and BENJAMIN GUIN**
}

This draft: 2 December 2014

\begin{abstract}
We study the exposure of mortgage borrowers in Switzerland to interest rate, income and house price risks and examine how the households' choice of risky mortgages is related to individual interest rate expectations and risk-aversion. Our analysis is based on a unique data set of household mortgage applications from September 2012 until January 2014. Our assessment of risk exposure among mortgage borrowers in Switzerland is highly sensitive to the underlying assumptions on mortgage costs, household income and house value. Our main results suggest that the exposure of mortgage borrowers to interest rate and house price risks is limited in the medium-term. We further document that the choice of mortgage contract seems to be more influenced by affordability concerns than risk concerns. In particular, individual interest rate expectations hardly affect mortgage contract choice.
\end{abstract}

JEL Codes: $\quad$ G21, D14, R21, R31

Keywords: $\quad$ Mortgage Default, Mortgage Choice, Household Finance, Mortgage Risk

\footnotetext{
* University of St.Gallen, Rosenbergstrasse 52, CH-9000 St.Gallen, Switzerland, martin.brown@unisg.ch.

${ }^{* *}$ University of St.Gallen, Rosenbergstrasse 52, CH-9000 St.Gallen, Switzerland, benjamin.guin@unisg.ch.

This study was conducted in cooperation with MoneyPark. We thank Stefan Heitmann, Valentin Rüst, Christoph Basten, Pius Matter, Kristian Blickle, Roland Füss and Zeno Adams for helpful comments. Furthermore, we thank Roland Füss and Zeno Adams for providing data on regional house prices. All remaining errors are our own.
} 


\section{Introduction}

The Swiss housing and mortgage markets have experienced significant developments over the past decade. Home ownership rates, still low by European standards, increased from 34.6 percent to 37.2 percent between 2000 and $2012 .{ }^{1}$ During the same period, prices for single-family houses and condominiums experienced a cumulative increase of $58 \%$ and $86 \%$, respectively. ${ }^{2}$ The increase in home ownership and the rise in house prices have arguably been fuelled by historically low interest rates. Rising incomes and immigration have put additional pressure on housing demand, especially in the urban agglomerations. ${ }^{3}$ Mirroring these developments in the real estate market, the volume of mortgage lending by banks has increased from 462 billion CHF in 2000 (106\% of GDP) to 860 billion CHF (145\% of GDP) in $2012 .{ }^{4}$

In light of these developments, policymakers have expressed deep concern that an increase in interest rates or a downward correction of house prices may compromise financial stability. ${ }^{5}$ Exposure to credit risk from mortgage lending is of first-order importance for the Swiss banking sector as mortgage loans dominate the domestic asset holdings of almost all banks. Since 2012 two macroprudential measures were introduced, aimed at mitigating credit risk in the mortgage market. In July 2012 the members of the Swiss Banking Association agreed to implement tighter equity requirements for mortgage borrowers requiring them to contribute at least $10 \%$ of own funds that are not part of their $2^{\text {nd }}$ pillar retirement savings. In February 2013, the federal government, following a request by the Swiss National Bank, activated an anticyclical capital buffer which required banks to hold capital of one percent of risk-weighted assets by September 2013. ${ }^{6}$ These requirements were subsequently increased to two percent to be held by July $2014 .{ }^{7}$

The goals of this paper are twofold. First, we examine to what extent the concerns of Swiss regulators over developments in the housing and mortgage markets are warranted. Using a novel data set of recent mortgage applications we obtained from an independent mortgage broker ${ }^{8}$, we

\footnotetext{
${ }^{1}$ http://www.bfs.admin.ch/bfs/portal/de/index/themen/09/03/blank/key/bewohnertypen/nach_region.html

${ }^{2} \mathrm{http}: / / \mathrm{www}$.wuestundpartner.com/en/publikationen/publikationen-schweiz/immobilienmarkt-schweiz.html

${ }^{3}$ See DEGEN and FISCHER (2010) as well as BASTEN and KOCH (2014) for an analysis of the impact of immigration and income growth on regional house prices.

${ }^{4}$ Including residential mortgages and mortgages for commercial and investment purposes http://www.snb.ch/en/iabout/stat/statpub/bchpub/stats/bankench.

${ }^{5}$ See for example the 2010 \& 2013 Financial Stability Reports of the Swiss National Bank.

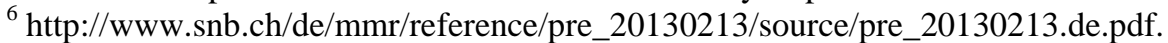

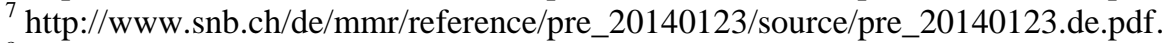

${ }^{8}$ The data were analyzed under a confidentiality agreement with MoneyPark.
} 
quantify the exposure of borrowers to potential interest rate, income and house price risks over the medium-term of up to five years and the long-term. ${ }^{9}$

Second, we use our data to analyze which households take risky mortgages. In particular, we analyze how households' interest rate expectations, house-price expectations and individual risk aversion affect mortgage contract choice. In our analysis we focus on short-and medium-term payment risk by investigating the choice of mortgages with variable interest rates and short maturities.

We present three main results: First, aggregate exposure of mortgage borrowers to interest rate and house price risks could be significant in the long term, but is limited in the medium-term. That said, we document that the assessment of exposure to interest rate risk and house-price risk in the mortgage market is highly sensitive to the underlying assumptions on mortgage costs, income and house value. ${ }^{10}$ Third, we show that the choice of mortgage contracts seems to be more influenced by affordability concerns than risk concerns. In particular, individual interest rate expectations hardly affect mortgage contract choice.

This paper is related to two strands of literature. Our analysis quantifying aggregate mortgage risks builds on several recent studies exploring the importance of interest rate, income and house price shocks in explaining the surge of mortgage defaults in the U.S. and Europe from 2007 onwards. The picture emerging from studies for the U.S. shows that the combination of all three types of shocks adversely affected the liquidity and solvency of mortgage borrowers (DEMYANYK and VAN HEMERT, 2011; ELUL et al., 2010) and could trigger default as a result of it (ELMER and SEELIG, 1999). ${ }^{11}$ Similar to MCCARTHY and MCQUINN (2011) (in case of Ireland) and IMF (2012) (in case of Spain), we quantify the aggregate exposure to interest rate risks by estimating the share of households applying for mortgages with high payment-toincome (PTI) ratios. We implicitly discuss the role of income risks by examining the sensitivity of our results to various definitions of household income. In addition, we gauge the exposure to

\footnotetext{
${ }^{9}$ A regional disaggregation of these risks is not possible as most mortgages were filed for properties located in or close to Zurich (as illustrated in Appendix 3).

${ }^{10}$ Our data set does not contain information on the actual mortgage costs (i.e. interest rates to be paid). Instead, we consider different scenarios in which we make assumptions on the interest paid for the mortgage and costs for upkeep of the property.

${ }^{11}$ As mortgage lenders in Switzerland have full recourse to the assets and the income of defaulting borrowers, it is unlikely that a severe decline in house prices, and corresponding negative home equity, would lead to strategic defaults of solvent households as analyzed, for example, by GUISO, SAPIENZA, and ZINGALES (2013) or GHENT and KUDLYAK (2011).
} 
house price risk by estimating the share of households with a high loan-to-value (LTV) ratios and limited unencumbered financial assets.

This paper also contributes to the empirical literature on household mortgage choice. Building on the normative predictions of the workhorse model by CAMPBELL and COCCO (2003), the existing literature has predominately analyzed the choice between fixed-rate mortgages (FRM) and adjustable-rate mortgages (ARM) with respect to potential income risk (COULIBALY and LI, 2009; EHRMANN and ZIEGELMEYER, 2014), the role of interest rate risk (COULIBALY and LI, 2009; BADARINZA, CAMPBELL, and RAMADORAI, 2013) or borrowing constraints (JOHNSON and LI, 2011; DAMEN and BUYST, 2013). While the choice between ARM and FRM sheds some light on the potential exposure to interest rate risk, it is only one indicator of the riskiness of a mortgage contract. As discussed in detail below, the loan maturity is an important determinant of exposure to interest rate risk as well as house price risk. We therefore also examine the propensity of households to choose short-term as opposed to long-term mortgages.

The remainder of the paper is organized as follows. Section 2 provides a theoretical framework to guide our empirical analysis. Section 3 presents the data. Section 3 quantifies the exposure of mortgage applications to interest rate and income risks. Section 4 gauges the aggregate exposure to house price risks. Section 5 analyzes household characteristics relevant for choosing mortgages particularly exposed to interest rate and house price risks. Section 6 concludes.

\section{Theoretical framework}

In this section we develop the empirical hypotheses based on a model which illustrates how interest rate, income and house price risks can affect the solvency of mortgage borrowers and can lead to default. Our model is adapted from ELMER and SEELIG (1999) who study the concepts of insolvency and trigger events into the theory of household mortgage default using a stylized three-period model. ${ }^{12}$

\section{Model}

We assume that a household lives for three periods.

\footnotetext{
12 In contrast to ELMER and SEELIG (1999), we discuss the option to strategically default and refinance prematurely as these are of little relevance given the institutional features of the Swiss mortgage market.
} 
- In period 1 the household chooses to buy a house of size $H$. The price per unit of housing is normalized to 1 . The household finances the house with initial wealth $w$ and a mortgage $m$.

- In period 2 the household pays interest on the mortgage $r \cdot m$ and consumes non-durable goods $c$. To finance consumption and interest payments the household yields an income income $y$ in this period. The household can additionally borrow $b>0$ or save $b<0$ in period 2 .

- In period 3 the household sells the house at price $p \cdot H$, and pays back the mortgage principal $m$ as well as any outstanding consumer credit (principal plus interest) $b \cdot(1+$ i).

We assume that the interest on the mortgage $r$, household income $y$ as well as the resale price of the house prices $p$ are stochastic and unknown in period 1. Their realized values are revealed at the beginning of period 2. We assume that in period $t=1$ the household forms expectations about future interest rates $E[r]=\bar{r}$, house prices in the last period $E[p]=\bar{p}$ and future income $\mathrm{E}[y]=\bar{y}$.

We assume that the household is risk-neutral. At $t=1$ the household and chooses an optimal lifecycle consumption pattern $\left(H^{*}, c^{*}\right)$ to maximize expected utility

$$
\max E[U(H, c)]=U(H, E[c])
$$

subject to:

$$
\begin{aligned}
& m=H-w \\
& \bar{c}=\overline{\mathrm{y}}-m \bar{r}+b \\
& \bar{p} H=m+b(1+i)
\end{aligned}
$$

The resource constraints $(1 \mathrm{~b}, 1 \mathrm{c}, 1 \mathrm{~d})$ can be merged to the following constraint which summarizes the tradeoff of the household between housing and expected consumption of non-durable goods:

$$
\bar{c}=\bar{y}-(H-w) \bar{r}+\frac{\bar{p} H-(H-w)}{(1+i)}
$$


In period 1 the households implements the consumption plan $\left(H^{*}, \bar{c}^{*}\right)$ by buying a house of size $H^{*}$ which it finances with a mortgage of $m=H^{*}-w$.

At the beginning of period 2 the actual household income, the mortgage interest rate and the resale price of housing are revealed: $y, r, p$. This implies that the realized consumption of nondurable goods in period 2 will be given as:

$$
c=\mathrm{y}-(H-w) r+\frac{p H-(H-w)}{(1+i)}
$$

\section{Insolvency vs. Illiquidity}

A household is insolvent if its cash inflows from income and expected house price gains cannot support its cash outflows due to mortgage interest and principal. From (3) we see that this would be the case if the household would have to incur negative consumption of non-durable goods, i.e.

$$
\mathrm{y}+\frac{p H-(H-w)}{(1+i)}<(H-w) r
$$

From (4) it is straight forward to see that income risk $(\mathrm{y}<\bar{y})$, interest rate risk $(r>\bar{r})$ and house price risk $(p<\bar{p})$ can all lead to the insolvency of the household.

Using equation (3) we can also clarify in which cases in the household is solvent but illiquid. Consider a sharp decline in household income $(\mathrm{y}<\bar{y})$ or a sharp increase in mortgage interest rates $(r>\bar{r})$. Now consider the case in which - due to house price gains - the expected cash flows of the household in period 3 is positive and total cash inflows of the household still exceed total cash outflows. As long as the household has access to consumer credit (i.e. a home-equity loan) the household can bring positive cash flows from period 3 forward to period 2 in order to bolster current income. However, if the consumer credit market is not available to the household it would have to default on current mortgage payments the mortgage due to illiquidity if

$$
\mathrm{y}+\frac{p H-(H-w)}{(1+i)}>(H-w) r>\mathrm{y}
$$




\section{Implications for the empirical analysis}

Our model shows that rising interest rates or declining household incomes may temporarily affect the ability of households to meet mortgage installments. Such liquidity shocks may trigger delinquencies on mortgage installments if households do not have access to alternative sources of formal credit (consumer credit, credit cards) or informal credit (families, friends). Hereby, liquidity constraints are most likely to be binding for households which are already highly leveraged (ELMER and SEELIG, 1999).

Severe shocks to interest rates and income may also trigger default on mortgage installments due to insolvency: households are not able to meet outstanding mortgage obligations with their expected future cash-flow. For the same reason, severe declines in house prices may trigger mortgage default. Households may still be able to meet current mortgage installments out of their net income per month. However, house price shocks imply that a sale of the house or mortgage refinancing would not yield sufficient funds to repay the outstanding balance on the existing mortgage as the current loan contract expires. ${ }^{13,14}$

These considerations suggest that a significant increase in interest rates may lead to delinquencies on monthly mortgage installments. Interest rate risk is largest for households with a high payment-to-income (PTI) ratio, adjustable-rate mortgages or fixed-rate mortgages with short maturities. By contrast, severe house price corrections may lead to defaults on final principal payments for maturing mortgage contracts. House price shocks pose a risk especially for households with high loan-to-value (LTV) ratios and no additional financial assets. Moreover, house price shocks are most likely to lead to defaults on mortgages which are close to maturity, as these borrowers may have to refinance their mortgage before prices recover.

\footnotetext{
${ }^{13}$ Note that margin calls are not typical in Switzerland for ongoing mortgage contracts, i.e. banks do not ask existing mortgage borrowers for additional equity in case of house price depreciations.

${ }^{14}$ This line of reasoning relies on the assumption that house prices are actually re-evaluated when mortgages are refinanced. We argue that this is a reasonable assumption as MoneyPark advisors have discretion and use information on the initial house price but also take temporary regional house price variations into account.

Besides, we would like to clarify that MoneyPark advisors essentially mimic bank loan officers' decisions in order to increase the probability of acceptance of the mortgage applications. Hence, it is reasonable to assume that temporary regional house price variations do matter for the mortgage refinancing decision of the bank.
} 


\section{Data}

In order to assess the exposure of mortgage borrowers to interest rate risk, income risk and house price risk we rely on information on the distribution of mortgage affordability (PTI) and household leverage (LTV). In addition, we use information on the interest rate type and maturity of mortgages as well as on the income sources and financial assets of households. We obtain a random sample of 325 first-time mortgage applications for owner-occupied properties processed through an independent mortgage broker in Switzerland between September 2012 and January 2014. This independent broker initially operated only one branch in Zurich. During our observation period it opened branches in Basel and Lucerne. Hence, the majority of households applying for mortgages live in or close to Zurich. Besides, the majority of applications (about $74 \%$ ) were filed at the Zurich branch and 10 out of 14 financial advisors were employed at this branch (as of January 2014).

Our sample covers only mortgage applications for owner-occupied properties at the independent mortgage broker during this time period. We consider only first-time mortgage applications and exclude applications to refinance existing mortgages from the initial sample. We restrict our sample as existing mortgage borrowers usually have repaid a substantial share of the principal. Hence, the loan to value (LTV) ratios of their mortgages are substantially lower and not comparable to first-time borrowers. The data set consists of only mortgage applicants that are located in the German-speaking part of Switzerland (as about 97 percent of all mortgage applicants are located in this part) and are not weighted by regions.

Table 1 provides descriptive statistics of key household characteristics covered in our sample. Definitions and summary statistics of all variables are provided in Appendix 1 and Appendix 2. Table 1 compares the characteristics of mortgage applications in our sample to the ones in a sample of mortgage borrowers from a representative survey of households in German-speaking Switzerland as reported by BROWN and HOFFMANN (2013). The table shows that the households covered in our sample over-represent what are commonly viewed as the mortgage borrowers most exposed to default risk in Switzerland: young, unmarried and high-income households. ${ }^{15}$ While BROWN and HOFFMANN (2013) include all mortgage borrowers

\footnotetext{
${ }^{15}$ This could indicate that the households covered in our sample target especially high price segments of the Swiss real estate market. In case of joint mortgage applications (e.g. in case of married couples), we focus on the main mortgage applicant responsible for the application with MoneyPark.
} 
including the ones that have outstanding mortgages, our sample includes only applications for first-time mortgages in the time period 09/2012-01/2014. We believe that this can explain some of the observed differences in age and marital status as first-time borrowers are presumably younger and are less likely to be married. ${ }^{16}$ As the applications in our data set were filed during a period of time when house prices were at an historical peak ${ }^{17}$, low- and middle wealth households might be particularly credit-constrained as they were not able to provide a sufficient amount of equity and collateral necessary to take out a mortgage. This might have amplified the observed differences in wealth and income. Last, all applicants have to file a preliminary request online before meeting the financial advisor in person. Hence, the application process requires some IT skills. That is why, we expect clients of this independent broker to be on average younger and to have a higher level of education compared to average bank clients.

While our data set might not be representative with respect to all existing mortgage borrowers in Switzerland, it is a policy-relevant sample as it indicates the risks associated with new mortgage applications. Understanding these risks is particularly important given the low interest rates and high house prices in the period considered. In a similar data set of broker-related mortgage applications in Switzerland, BASTEN and KOCH (2014) show that the mortgage applicants are similar in the key socio-economic characteristics we present below (the mean age in their sample is 46 (in 2013), median household income is CHF 150'000 (in 2013), median financial wealth is CHF 285'000 (in 2013)). ${ }^{18}$

[ Table 1 ]

\footnotetext{
16 In the data set used by BROWN and HOFFMANN (2013), one cannot disentangle borrowers of existing mortgages from new mortgage borrowers. Furthermore, one cannot disentangle first-time mortgage borrowers from borrowers that take mortgage to refinance existing mortgage contracts.

${ }_{17}^{17}$ As illustrated in Appendix 4.

18 BASTEN and KOCH (2014) use data obtained from Comparis.ch which is a Swiss online company that intermediates mortgages. While the summary statistics in BASTEN and KOCH (2014, p.41) are based on observations from 2008 until 2013, the values reported in the text above are based on observations from only 2013 to make them comparable to our data.
} 
Panel A of Table 2 provides summary statistics of the mortgages applied for by the households in our sample. The median total loan amount is $662^{\prime} 000 \mathrm{CHF}$ compared to a median property value of 920'000 CHF and a median annual gross household income of 185'800 CHF. Again, these values compare well to BASTEN and $\mathrm{KOCH}$ (2014) that report a median loan amount of 500 '000 CHF, a median property value of 820'000 CHF and (both in 2013).

More than half the first-time borrowers apply for two mortgage tranches. Mortgage applications are dominated by long-term, fixed interest rate tranches. In our sample $74 \%$ of the total mortgage volume applied for features a fixed interest rate, while $88 \%$ of the applications feature at least one fixed rate tranche. Also, $63 \%$ of the mortgage volume has a long term maturity (more than 5 years) while $79 \%$ of the applications feature a long-term tranche (more than 5 years).

Panel B of Table 2 shows the distribution of key mortgage application characteristics depending on the total loan amount. While the shares of fixed rate mortgages, variable rate mortgages and mortgages with long maturity (of more than 5 years) differ only marginally across loan sizes, there are slight differences in the number of tranches: Very small mortgages have on average fewer tranches (1.30 tranches) than very large mortgages (2.06 tranches).

[ Table 2 ]

It is important to notice that this data set includes only one cohort of mortgage applicants at origination. We neither observe these households at a later point in time nor do we observe mortgage applicants that took mortgages in the past. Hence, the data does not include information on how mortgages are amortized and how the characteristics of mortgage takers (e.g. changes in household income or size) evolve over time.

We complement our sample of mortgage applications with regional data on house prices. To capture potential house price bubbles, we employ two proxies: First, we use the price-to-rent ratio 
per MS Region in 2012. ${ }^{19}$ Second, we use the change of average house prices between 2003 and 2012 on the MS Region level. For both proxies, very large values indicate potential house price bubbles which may lead households to expect downward corrections of house price in the future. The regional distributions of these proxies are illustrated in Appendix 3.

We consider a ten-year period from 2003 until 2012 as prices for single family houses were at historically low levels in 2003 (see Appendix 4). Appendix 4 also shows that the major price decline in the last house price cycle occurred in the first five years after the peak (between 1990 and 1995). This is why we focus our analysis on house price corrections over a time period of five years.

\section{Exposure to interest rate risk and income risk}

We first assess the exposure of mortgages in our sample to interest rate risk and income risk. Hereby, we analyze whether borrowers could afford the annual interest payments and costs for upkeep of the property if interest rates returned from the historically low levels to their long term average (5\% p.a.). Figure 1 shows the distribution of payment to income (PTI) ratios in our sample. We display four different PTI ratios which vary in their assumptions regarding financing costs and household income. The solid black line displays PTI ratios based on a calculatory interest rate of $5 \%$ p.a. on the total loan amount plus $1 \%$ p.a. upkeep on the property value. The corresponding annual payments are divided by total annual income of the household (including variable wage components and capital income). The dashed blue line displays PTI ratios in which mortgage costs additionally account for $1 \%$ p.a. amortization of the loan. Here, the PTI ratio is based on annual payments of $6 \%$ of the loan value (5\% interest and $1 \%$ amortization) plus $1 \%$ on the property value for upkeep. The dotted red line displays PTI ratios again based on payments which account for interest, upkeep and amortization. Here, the total annual payments of $6 \%$ of the total loan amount plus $1 \%$ on the house value are now divided by a more conservative income measure: we exclude all capital income and variable wage components of the household and take into account only the fix wage income of the household. Last, the dashed-dotted orange line shows PTI ratios of $6 \%$ of the total loan amount plus $1 \%$ on the house value but we now divide

\footnotetext{
19 The ratio is based on the UBS Swiss Real Estate Bubble Index but house prices and rental rates are weighted according to the average number of rooms per MS Region. Switzerland is partitioned into 106 MS regions which largely represent local labor markets.
} 
by an even more conservative income measure: In case of married couples, we take the main fix wage income source.

\section{[ Figure 1]}

Figure 1 shows that the assessment of the exposure of mortgage applicants to interest rate risk and income risk is strongly dependent on which mortgage costs are considered. At an interest rate of $5 \%$ p.a. plus $1 \%$ p.a. upkeep on the house value we find that only $5 \%$ of the mortgage applicants in our sample would face annual mortgage payments which exceed one-third of their total annual household income (solid black line). However, once we account additionally for the costs of mortgage amortization the share of households exposed to interest rate risk increases sharply. The dashed blue line shows that more than $20 \%$ of current applicants would have payments exceeding one-third of their income, once we additionally account for $1 \%$ p.a. amortization on their mortgage.

Figure 1 also shows that the assessment of the exposure of mortgage applicants to interest rate risk and income risk is strongly dependent on which income components are considered. When we exclude variable income components from total household income (dotted red line), and again account for costs of interest payments, upkeep of the house and amortization of the mortgage we find that $33 \%$ of all applicants would face annual payments exceeding one-third of their fix wage income. ${ }^{20}$ Moreover, when considering only the main fix wage income, close to two-thirds of all mortgage applicants face annual payments exceeding one-third of their income (dashed-dotted orange line). The latter findings suggest that the loss of the secondary income (rather than the reduction of variable income components) is the main potential risk which households are exposed to in terms of current installment payments.

\footnotetext{
${ }^{20}$ As illustrated by the figure in Appendix 5, the share of applicants that would face annual payments exceeding onethird of their fix wage income varies tremendously depending on the assumptions on interest payments. It ranges from 0.04 (total annual payments of $4 \%$ of the total loan amount plus $1 \%$ for upkeep) to 0.53 (total annual payments of $7 \%$ of the total loan amount plus $1 \%$ for upkeep).
} 
[ Table 3 ]

In Table 3 we consider mortgages as potentially exposed to interest rate shocks if total annual payments of $6 \%$ of the total loan amount plus $1 \%$ for upkeep would exceed their fix wage income by more than one-third (Panel A). This is the case for one-third of the households in our sample (see dotted red line in Figure 1). In the table we examine the interest rate sensitivity of these applications and compare them to applications with low PTI ratios. Table 3 shows that mortgage applications with high PTI ratios are not more sensitive to short-term interest rate changes than applications with low PTI ratios. The share of mortgages with adjustable interest rates or mortgages with medium-term fixed-rate mortgages (maturity of not more than 5 years) is low and similar among high PTI loans (39\%) and low PTI applications (37\%). We obtain qualitatively similar results when calculating the PTI loans using total income instead of the fix wage income (Panel B). ${ }^{21}$ Overall, these results suggest that the effective exposure to medium-term interest rate hikes over a time period of 5 years is limited in our sample of mortgage applicants, and is not concentrated among households with high payment to income ratios. ${ }^{22}$

\section{Exposure to house price risk}

The exposure of mortgages to house price risk depends on the leverage of households as well as on additional asset holdings of households. Moreover, as house price risk affects mortgages at contract expiry, the time-to-maturity of the mortgage contract also influences whether temporary or medium-term shocks to house prices may trigger default.

Figure 2 displays the distribution of leverage in our sample. The solid black line displays a simple loan to value (LTV) ratio, calculated as the ratio of the mortgage volume to the sales price of the property. According to this measure $26 \%$ of the mortgage applications in our sample could be considered at risk to sharp house price corrections: they display LTV ratios of at least $80 \%$.

\footnotetext{
${ }^{21}$ Analyzing the exposure of PTI loans using total annual payments of only 5\% of the total loan amount plus $1 \%$ for upkeep over total income turns out to be not feasible as there is a very low number of observations in case of high PTI loans $(\mathrm{N}=18)$.

${ }^{22}$ We provide robustness tests using thresholds at $30 \%$ in Appendix 6 . The results remain qualitatively similar.
} 
This simple LTV ratio overstates the potential credit risk for lenders if mortgage borrowers pledge further collateral in addition to the mortgaged property, e.g. their pension fund, their security portfolios or life insurance. The dashed blue line in Figure 2 therefore displays the ratio of mortgage loan to the total collateral value, after adding further pledged collateral to the house value. Accounting for additional collateral we find that the share of mortgages with high leverage is slightly reduced: $21 \%$ of the applications have a loan to total collateral value of $80 \%$ or more. For almost all of these households, the ratio lies between $80-85 \% .^{23}$

\section{[ Figure 2 ]}

While a house price shock may impact on household net-wealth, this does not imply that it will trigger a mortgage default. First, if households have long-term mortgage contracts (and do not need to sell the house for exogenous reasons) they may not need to refinance their mortgage until house prices have recovered. Second, even if households need to refinance their mortgage in the medium term, they may be able to do so if they have free (unencumbered) financial assets. Table 4 examines the loan maturity and volume of free assets for mortgage applications with high LTV ratios (exceeding 80\%) and compares them to those for low LTV ratios (below or equal to 80\%).

[ Table 4 ]

Panel A of table 4 shows that most mortgage applicants do not have sufficient unencumbered liquid assets (employed as equity) to cushion a price shock if they had to refinance their mortgage

\footnotetext{
${ }^{23}$ There is evidence that the LTV ratios are binding: Among the 114 applicants with loan to value and other collateral ratios between 0.78 and 0.81 , the share of applicants that employ their Pillar 3 retirement savings accounts as collateral or equity is 0.46 . This share is substantially higher than among applicants with ratios below 0.75 (share of 0.32 ). A LTV ratio of 0.80 is the typical threshold for the acceptance of mortgage applications by banks.
} 
after a price shock. ${ }^{24}$ The share of applicants with a ratio of free liquid assets over total mortgage value of more than 10 percent is low among high-LTV applicants (18\%) and much lower than among low-LTV applicants (36\%). When we additionally consider illiquid financial assets (pension funds, life insurance) the share of households with sufficient total financial wealth to cushion a significant shortfall at the time of mortgage refinancing increases substantially. However, the share of households with sufficient free assets is still much lower for high LTV applications than for low LTV applications.

In Panel B of table 4, we analyze the loan maturity of the mortgages that are most exposed to house price risks. Our indicator of interest is the share of tranches with maturities of not more than 5 years. We compare this indicator for applicants with high vs. low LTV mortgages among those households with only a limited amount of free liquid assets. We find that the share of mortgage tranches with short maturities is smaller for applicants with high LTV ratios (31\%) than for applicants with low LTV mortgages (36\%). We interpret this as evidence that the risk associated with house price adjustments is limited in the medium term of up to 5 years. ${ }^{25}$

\section{Which households take risky mortgages?}

Our analysis above shows a substantial variation in the choice of contracts across mortgage borrowers and consequently in their potential exposure to interest rate risk and house price risk. In this section we conduct a mortgage-level regression analysis to examine which households choose risk mortgages. In particular we are interested to what extent individual interest rate expectations and risk aversion as well as local house price developments affect mortgage contract choice.

We employ two dependent variables to measure the exposure of a mortgage applicant to interest rate risk and house price risk. Our first indicator Share with variable interest rate measures the

\footnotetext{
${ }^{24}$ As shown in Appendix 4, within the first five years of the last house price decline, the prices declined by about 1020 percentage points. This decline would have to be made up by free financial assets. Hence, we employ a threshold of 10 percent.

${ }^{25}$ We show in Appendix 7 that the results are robust when employing LTV thresholds of $70 \%$. Furthermore, we show in Appendix 8 that our results remain qualitatively similar when considering only high price regions. We cannot conduct a subsample analysis similar to Table 4 Panel B given the relatively low number of observations in high price regions (Appendix 8).
} 
share of the mortgage which bears a variable interest rate. Our second indicator Share with maturity $<=5$ years measures the share of the mortgage with a short to medium term maturity. ${ }^{26}$

To gauge the household-level expectations on future interest rates, we use a binary measure of self-reported interest rate expectations: The variable Expected interest increase takes on the value of one if the household expects interest rates to increase in the future (zero otherwise). As it can be seen from Appendix 2, there is substantial heterogeneity in these expectations: about onefourth of the households in the sample expect interest rates to rise, whereas the other applicants expect them to stay at low levels. ${ }^{27}$ Households that expect interest rates to increase should be ceteris paribus less likely to choose variable interest rate mortgages. Instead, they should be more likely to choose long-term mortgages that are usually fixed rate. ${ }^{28}$

To gauge the effect of risk-aversion on individual mortgage choice, we rely on a measure of selfreported risk aversion (Risk averse) which is a binary variable taking on the value of one if the credit applicant reports to have a relatively low risk tolerance (zero otherwise). It can be seen from the summary statistics presented in Appendix 2 that more than one third of the individuals consider themselves as risk averse. Furthermore, we include interaction effects between risk aversion and interest rate expectations and the two proxies for house price risks to analyze whether risk averse person respond more strongly to these risk factors.

Unfortunately, we do not have a direct measure of households' house price expectations. To quantify households' exposure to house price risks, we therefore employ two variables which measure the level and development of local house prices: the natural logarithm of the change of the house prices over the period 2003-2012 (D.Price (2003-2012) (Ln)) and the natural logarithm of the price-to-rent ratio in 2012 (Price to rent ratio (2012) (Ln)). As shown in Appendix 2 \&

\footnotetext{
${ }^{26}$ We exclude 30 observations that were filed with an advisor that stopped working for MoneyPark as we cannot identify the advisor ID in the data set: As shown in Appendix 9, the observable characteristics of missing observations are not systematically different from the characteristics of observations included in the regressions.

${ }^{27}$ Households were neither asked when they expected interest rates to increase nor by how much they expected interest rates to increase.

${ }^{28}$ Analyzing the effect of actual interest rates on mortgage choice is beyond the scope of this paper as our data set does not include the actual interest rate offered by the banks. Exploiting the time variation of aggregate interest rates to identify the effect of actual interest rate changes on mortgage choice proved to be impossible: The 3 month Swiss franc LIBOR interest rate - which is relevant for mortgage pricing - was at historically low levels in the time period considered: It varied only marginally between $0.04 \%$ and $0.02 \%$.
} 
Appendix 3, these ratios vary substantially across MS Regions ranging from 1 to 21 (D.Price (2003-2012)) and from 32 to 55 (Price to rent ratio (2012)).

The use of current price-to-rent levels and past house price changes, rather than expected future house price developments makes it difficult to infer from our analysis how house price expectations affect mortgage contract choice. On the other hand, high house prices indicate a possible risk of house price corrections in the future. Hence, households might want to take mortgages with longer maturities (that are usually fixed rate) such that they can repay a substantial amount of their principal before refinancing. On the other hand, high house price levels may imply that less-risky mortgage contracts (long-term, fixed rate) are not affordable for some households. Hence, they might be more inclined to choose more affordable - but also more risky - short-term, variable rate contracts.

In all regressions, we control for household income levels and the associated income risk as proxied by the variables Fix wage income, Bonus payment and Self-employed. In addition, we control for the natural logarithm of household wealth (Liquid assets and Illiquid assets), gender, age and marital status of the applicant. Furthermore, we include dummy variables that indicate whether the household owned additional real estate and had further debt. ${ }^{29}$ As each mortgage application is filed jointly with a financial advisor, we include advisor dummy variables in each regression to control for the potential influence of advisor's preferences on the individual mortgage choice (as, for example, MULLAINATHAN, NOETH, and SCHOAR (2012) show that financial advice matters regarding portfolio investment choice).

We estimate the effects of individual interest rate expectations, risk aversion and regional house prices on the interest sensitivity and maturity of the chosen mortgages using a linear probability model and show the results in table 5. The dependent variables are the share of variable interest rate mortgage tranches relative to the total loan amount (columns 1-4) and the share of mortgage tranches with maturity of five years or less relative to the total loan amount (columns 5-8). These variables take on values between 0 and 1 .

The estimated coefficients of Expected interest increase in Table 5 provide no evidence that interest rate expectations have an impact on mortgage contract choice at the household level.

\footnotetext{
${ }^{29}$ We only observe whether the applicant serviced debt but not the level of debt. Hence, we create a dummy variable that takes on the value of one if the credit applicant's annual debt service (other than the mortgage) is more than $10 \%$ of the fix wage income.
} 
Households which expect interest rate increases are not less likely to choose variable rate contracts (columns 1-4). Besides, there is only little evidence that they choose short-term contracts (columns 5-8). While the interaction term Expected interest increase * Risk averse is estimated to be negative in all columns, none of the coefficients are significant.

The results in Table 5 suggest that regional house price developments have an impact on mortgage contract choice. There is evidence that ten percent increase in the Price to rent ratio (2012) is associated with an increase in the probability of choosing a short-term mortgage by about 6 percentage points. The effect of D.Price (2003-2012) is qualitatively similar. The fact that higher house prices lead to more risky mortgage contracts suggests that affordability issues rather than risk concerns - dominate mortgage contract in areas with housing price booms. However, the negative and significant coefficients of the interaction terms of D.Price (20032012) (Ln) * Risk averse (columns 2 \& 6) and Price to rent ratio (2012) (Ln) * Risk averse (column 7) suggest that concerns over potential house price corrections are also relevant for mortgage contract choice: Risk averse households are more likely to choose long-term, fixed-rate contracts in areas which have especially high house prices.

[ Table 5 ]

\section{Summary and conclusion}

Given the medium-term risk of higher interest rates and house price corrections in Switzerland, it is important for regulators and banks to have a comprehensive assessment of the exposure of mortgage borrowers to interest rate and house price risks. Our analysis, based on a sample of recent mortgage applications, suggests that the long-term exposure to interest rate and house price risks could be significant, while the short-term or medium-term exposure is limited.

If interest rates return to their long term average (5\% p.a.) nearly one-quarter to one-third of the mortgage applicants in our sample would face total mortgage payments - including interest, amortization and costs of upkeep - that exceed a third of their total household income. Thus, a substantial share of current mortgage applicants is exposed to interest rate risk. However, the 
large share of mortgage applicants with high payment-to-income ratios choose long-term fixedrate contracts. Thus, an increase in interest rates would not have an immediate or medium-term impact on mortgage affordability. A severe correction to house prices could make it difficult for one in six borrowers to refinance their mortgages once their current loan expires. This is particularly the case as only a minority of mortgage applicants has sufficient unencumbered and liquid financial assets to cushion a price shock. Again though, most of the high-LTV applications are for long-term mortgages, suggesting that they will not have to refinance their current mortgage in the next five years. Thus, these borrowers are exposed only to prolonged decline in house prices rather than temporary or medium-term price slumps.

Overall, our analysis suggests that a rise in interest rates to their long-term level (5\%) and a downward correction of house prices (e.g. 20\%) would not lead to a significant increase in mortgage defaults in the short or medium term. However, a prolonged correction of house prices or a long-term rise in interest rates to their historical average - both experienced by Switzerland in the early 1990's - could drive a significant share of the most recent mortgages into default.

At the household-level we find - surprisingly - that individual expectations of interest increases do not induce households to choose more long-term, fixed rate contracts. Risk averse households are more likely to choose long-term, fixed rate contracts in areas characterized by risks of house price corrections. However, overall mortgage contract choice seems to be dominated by affordability concerns, rather than risk concerns. 


\section{References}

AREGGER, NICOLE, MARTIN BROWN, and ENZO ROSSI (2013), “Transaction Taxes, Capital Gains Taxes and House Prices”, Swiss National Bank Working Papers 2013-2.

BADARINZA, CHRISTIAN, JOHN CAMPBELL, and TARUN RAMADORAI (2013), "What Calls to ARMs? International Evidence on Interest Rates and the Choice of Adjustable-Rate Mortgages", Working Paper.

BASTEN, CHRISTOPH and CATHERINE KOCH (2014), "House Prices, Mortgage Demand and Mortgage Supply: Causal Evidence from a Shift-Share Experiment”, Working Paper, University of Zurich.

BROWN, MARTIN and MATTHIAS HOFFMANN (2013), "Mortgage Relationships", University of St. Gallen Working Papers on Finance 2013/10.

COULIBALY, BRAHIMA and GENG LI (2009), "Choice of Mortgage Contracts: Evidence from the Survey of Consumer Finances”, Real Estate Economics 37, 659-673.

DAMEN, SVEN and ERIK BUYST (2013), "The Myopic Choice between Fixed and Adjustable Rate Mortgages in Flanders", Working Paper.

DEGEN, KATHRIN and ANDREAS FISCHER (2010), "Immigration and Swiss House Prices”, Swiss National Bank Working Paper 2010-16.

DEMYANYK, YULIYA and OTTO VAN HEMERT (2009), "Understanding the Subprime Crisis”, Review of Financial Studies 24, 1848-1880.

EHRMANN, MICHAEL and MICHAEL ZIEGELMEYER (2014), "Household Risk Management and Actual Mortgage Choice in the Euro Area”, ECB Working Paper 1631.

ELMER, PETER and STEVEN SEELIG (1999), "Insolvency, Trigger Events and Consumer Risk Posture in the Theory of Single-Family Mortgage Default”, Journal of Housing Research $10,1-25$.

ELUL, RONEL, NICHOLAS SOULELES, SOUPHALA CHOMSISENGPHET, DENNIS GLENNON, and ROBERT HUNT (2010), "What "Triggers" Mortgage Default?", American Economic Review: Papers \& Proceedings 100, 490-494. 
GHENT, ANDRA and MARIANNA KUDLYAK (2011), "Recourse and Residential Mortgage Default: Evidence from US States”, Review of Financial Studies 24, 3139-3186.

GUISO, LUIGI, PAOLA SAPIENZA, and LUIGI ZINGALES (2013), "The Determinants of Attitudes towards Strategic Default on Mortgages”, Journal of Finance 68, 1473-1515.

IMF (2012), "Spain: Vulnerabilities of Private Sector Balance Sheets and Risks to the Financial Sector Technical Notes", IMF Country Report No. 12/140.

JOHNSON, KATHLEEN and GENG LI (2011), “Are Adjustable-Rate Mortgage Borrowers Borrowing Constrained?", Working Paper.

MCCARTHY, YVONNE and KIERAN MCQUINN (2011), "How Are Irish Households Coping with their Mortgage Repayments? Information from the Survey on Income and Living Conditions", The Economic and Social Review 42(1), 71-94.

MULLAINATHAN, SENDHIL, MARKUS NOETH, and ANTOINETTE SCHOAR (2012), “The Market for Financial Advice: An Audit Study", NBER Working Paper 17929. 
[ Appendix ] 
This table compares the characteristics of households applying for first-time mortgage applications at MoneyPark from September 2012 until January 2014 with the characteristics of households that had a mortgage loan in a representative survey of households in German-speaking Switzerland commissioned by the University of St. Gallen in 2011. The last column shows the mean differences. Definitions of the variables are provided in appendix $1 .{ }^{* * *}, * *$, * denote statistical significance at the $0.01,0.05$ and $0.10-$ level of two-sample t-tests respectively.

\begin{tabular}{l|cc|cc|c}
\hline \hline & \multicolumn{2}{c}{$\begin{array}{c}\text { MoneyPark } \\
\text { applications }\end{array}$} & \multicolumn{2}{c}{$\begin{array}{c}\text { Representative } \\
\text { Survey }\end{array}$} \\
\hline & Mean & Obs. & Mean & Obs. & Difference \\
\hline Household characteristics & & & & & \\
Age & 41.00 & 325 & 49.47 & 581 & $-8.47^{* * *}$ \\
City residence & 0.89 & 325 & 0.62 & 581 & $0.27^{* * *}$ \\
Married & 0.62 & 325 & 0.83 & 581 & $-0.21^{* * *}$ \\
\hline Annual income (Total household income) & & & & & \\
> CHF 180'000 & 0.53 & 325 & 0.09 & 581 & $0.44^{* * *}$ \\
CHF 144'000 - CHF 180'000 & 0.20 & 325 & 0.11 & 581 & $0.09^{* * *}$ \\
CHF 108'000 - CHF 144'000 & 0.15 & 325 & 0.23 & 581 & $-0.08^{* *}$ \\
$<$ CHF 108'000 & 0.12 & 325 & 0.56 & 581 & $-0.44^{* * *}$ \\
\hline Financial wealth (Liquid assets) & & & & & \\
$>$ CHF 1'000'000 & 0.04 & 325 & 0.03 & 581 & 0.01 \\
CHF 250'000 - CHF 1'000'000 & 0.51 & 325 & 0.11 & 581 & $0.40^{* * *}$ \\
CHF 100'000 - CHF 250'000 & 0.33 & 325 & 0.22 & 581 & $0.11^{* * *}$ \\
$<$ CHF 100'000 & 0.12 & 325 & 0.65 & 581 & $-0.53^{* * *}$ \\
\hline \hline
\end{tabular}


Table 2. Mortgage application characteristics

This table shows the characteristics of 325 first-time mortgage applications at MoneyPark from September 2012 until January 2014. Definitions of the variables are provided in appendix 1.

$\underline{\text { Panel A. Unconditional distributions of key mortgage application characteristics }}$

\begin{tabular}{|c|c|c|c|c|c|c|}
\hline & Mean & Min & $\begin{array}{r}0.25 \\
\text { percentile }\end{array}$ & $\begin{array}{r}0.50 \\
\text { percentile }\end{array}$ & $\begin{array}{r}0.75 \\
\text { percentile }\end{array}$ & Max \\
\hline Total loan amount & $731 ' 204$ & $126^{\prime} 000$ & $500 ' 000$ & $662 ' 000$ & $872 ' 000$ & $2^{\prime} 8800^{\prime} 000$ \\
\hline Share with fixed interest rate & 0.74 & 0.00 & 0.55 & 1.00 & 1.00 & 1.00 \\
\hline Share with variable interest rate & 0.26 & 0.00 & 0.00 & 0.00 & 0.45 & 1.00 \\
\hline Share with maturity $>5$ years & 0.63 & 0.00 & 0.43 & 0.68 & 1.00 & 1.00 \\
\hline Number of tranches & 1.74 & 1.00 & 1.00 & 2.00 & 2.00 & 4.00 \\
\hline $\begin{array}{l}\text { Property reference value } \\
\text {. }\end{array}$ & 1'028'157 & $176^{\prime} 000$ & $720 ' 000$ & $920 ' 000$ & 1'250'000 & $3^{\prime} 6000^{\prime} 000$ \\
\hline Total household income & $217^{\prime} 629$ & 35'409 & $140 ' 950$ & $185 ' 800$ & $250 ' 000$ & 1'144'500 \\
\hline
\end{tabular}

Panel B. Average mortgage application characteristics depending on total loan amount

\begin{tabular}{l|rrrr}
\hline \multicolumn{1}{c}{ Total loan amount } & [126'000; 500'000) & [500'000; 662'000) & [662'000; 872'000) & [872'000; 2'880'000] \\
\hline \hline Share with fixed interest rate & 0.74 & 0.74 & 0.76 & 0.71 \\
Share with variable interest rate & 0.26 & 0.26 & 0.24 & 0.29 \\
Share with maturity >5 years & 0.57 & 0.66 & 0.64 & 0.63 \\
Number of tranches & 1.30 & 1.69 & 1.90 & 2.06 \\
\hline Property reference value & $597^{\prime} 164$ & $834^{\prime} 106$ & $1^{\prime} 041^{\prime} 907$ & $1^{\prime} 621^{\prime} 415$ \\
Total household income & $142^{\prime} 950$ & $176^{\prime} 072$ & $215^{\prime} 018$ & $333^{\prime} 185$ \\
\hline \hline
\end{tabular}




\section{Figure 1. Cumulative distribution of payment to income ratios}

This figure shows cumulative distributions of payment to income ratios (PTI) for 325 first-time mortgage applications from September 2012 until January 2014. The solid black line indicates the distribution of the PTI using a calculatory interest rate of $5 \%$ on the loan amount and $1 \%$ upkeep on the property reference value as a share of total household income. The dashed blue line indicates the distribution of the PTI using a calculatory installment rate of $6 \%$ (5\% interest plus $1 \%$ amortization) on the loan amount and 1\% upkeep on the property reference value as a share of total household income. The dotted red line indicates the PTI using a calculatory installment rate of $6 \%$ on the loan amount (5\% interest and $1 \%$ amortization) and $1 \%$ upkeep on the property reference value as a share of fix wage income. The dashed-dotted orange line indicates the PTI using a calculatory installment rate of $6 \%$ on the loan amount (5\% interest and $1 \%$ amortization) and $1 \%$ upkeep on the property reference value as a share of the main fix wage income. Definitions of the variables are provided in appendix 1.
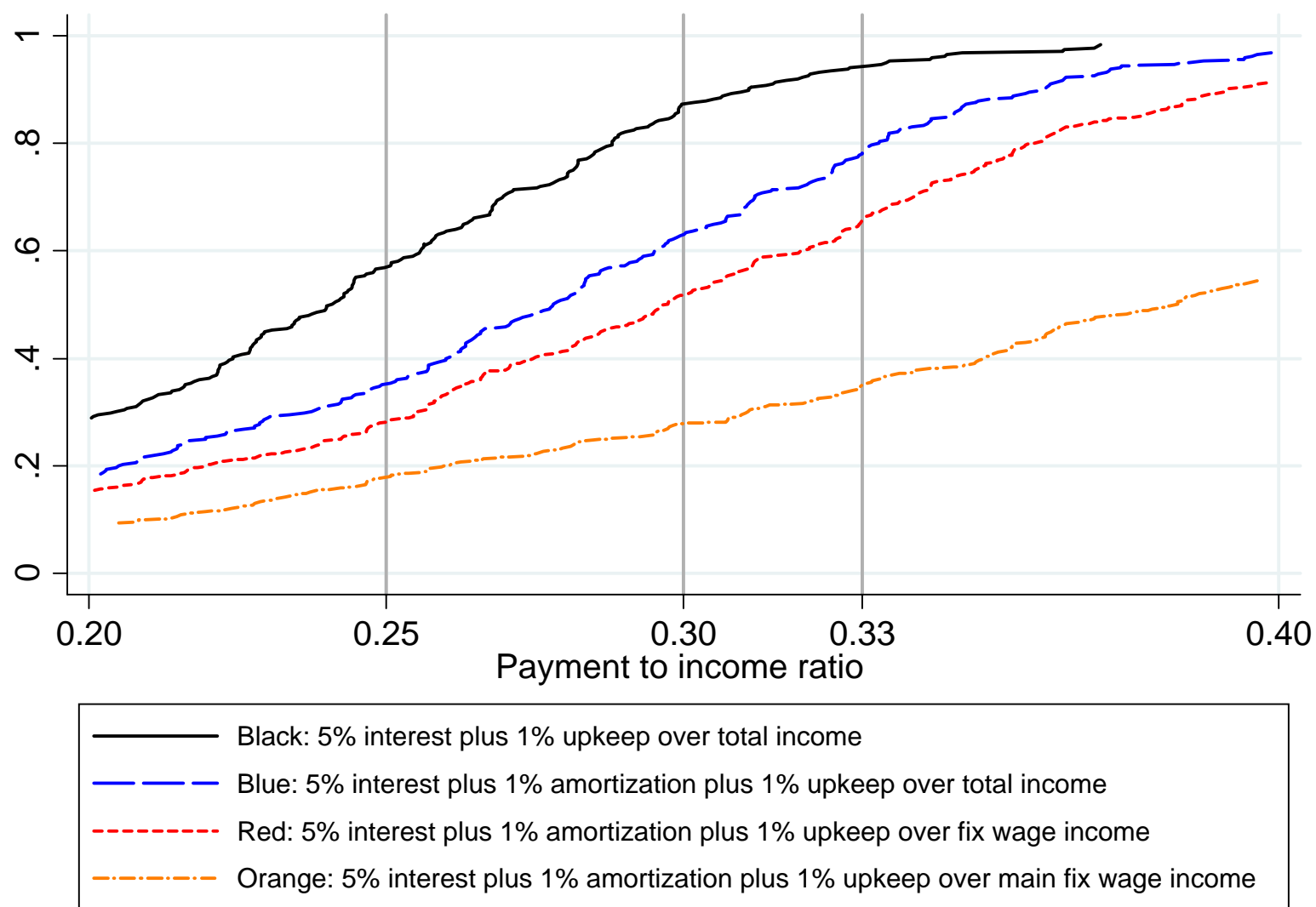
This table shows the mean share of first-time mortgage applicants asking for a variable interest mortgage or a fixed interest mortgage with maturity of not more than 5 years depending on whether the payment to income ratio is above or below 33\%. The last column tests the differences using univariate t-tests. The payment to income ratio is calculated using a calculatory interest rate of $6 \%$ on the total loan amount and $1 \%$ upkeep on the property reference value over fix wage income (Panel A), a calculatory interest rate of $6 \%$ on the total loan amount and $1 \%$ upkeep on the property reference value over total income (Panel B). Definitions of the variables are provided in appendix 1. ***, **, * denote statistical significance at the $0.01,0.05$ and 0.10 -level respectively.

Panel A. PTI calculated using $6 \%$ plus $1 \%$ for upkeep over fix wage income

\begin{tabular}{l|c|c|c}
\hline \hline Variable & PTI $>\mathbf{3 3 \%}$ & PTI $<=33 \%$ & Difference \\
\hline $\begin{array}{l}\text { Share with variable interest rate or } \\
\text { with fixed interest rate }<=5 \text { years }\end{array}$ & $\begin{array}{c}0.389 \\
(\mathrm{~N}=106)\end{array}$ & $\begin{array}{c}0.372 \\
(\mathrm{~N}=219)\end{array}$ & $\begin{array}{c}0.017 \\
(0.045) \\
(\mathrm{N}=325)\end{array}$ \\
\hline \hline
\end{tabular}

Panel B. PTI calculated using $6 \%$ plus $1 \%$ for upkeep over total income

\begin{tabular}{l|c|c|c}
\hline \hline Variable & PTI $>\mathbf{3 3 \%}$ & PTI $<=33 \%$ & Difference \\
\hline $\begin{array}{l}\text { Share with variable interest rate or } \\
\text { with fixed interest rate }<=5 \text { years }\end{array}$ & $\begin{array}{c}0.400 \\
(\mathrm{~N}=64)\end{array}$ & $\begin{array}{c}0.372 \\
(\mathrm{~N}=261)\end{array}$ & $\begin{array}{c}0.028 \\
(0.053) \\
(\mathrm{N}=325)\end{array}$ \\
\hline \hline
\end{tabular}


Figure 2. Cumulative distribution of loan to value ratios

This figure shows cumulative distributions of the loan to value ratios (LTV) for 325 first-time mortgage applications from September 2012 until January 2014. The solid black line indicates the distribution of the total loan amount over the property reference value. The dashed blue line indicates the distribution of the loan to total collateral ratio, i.e. we add other collateral pledged by the borrower to the property reference value. Definitions of the variables are provided in appendix 1.

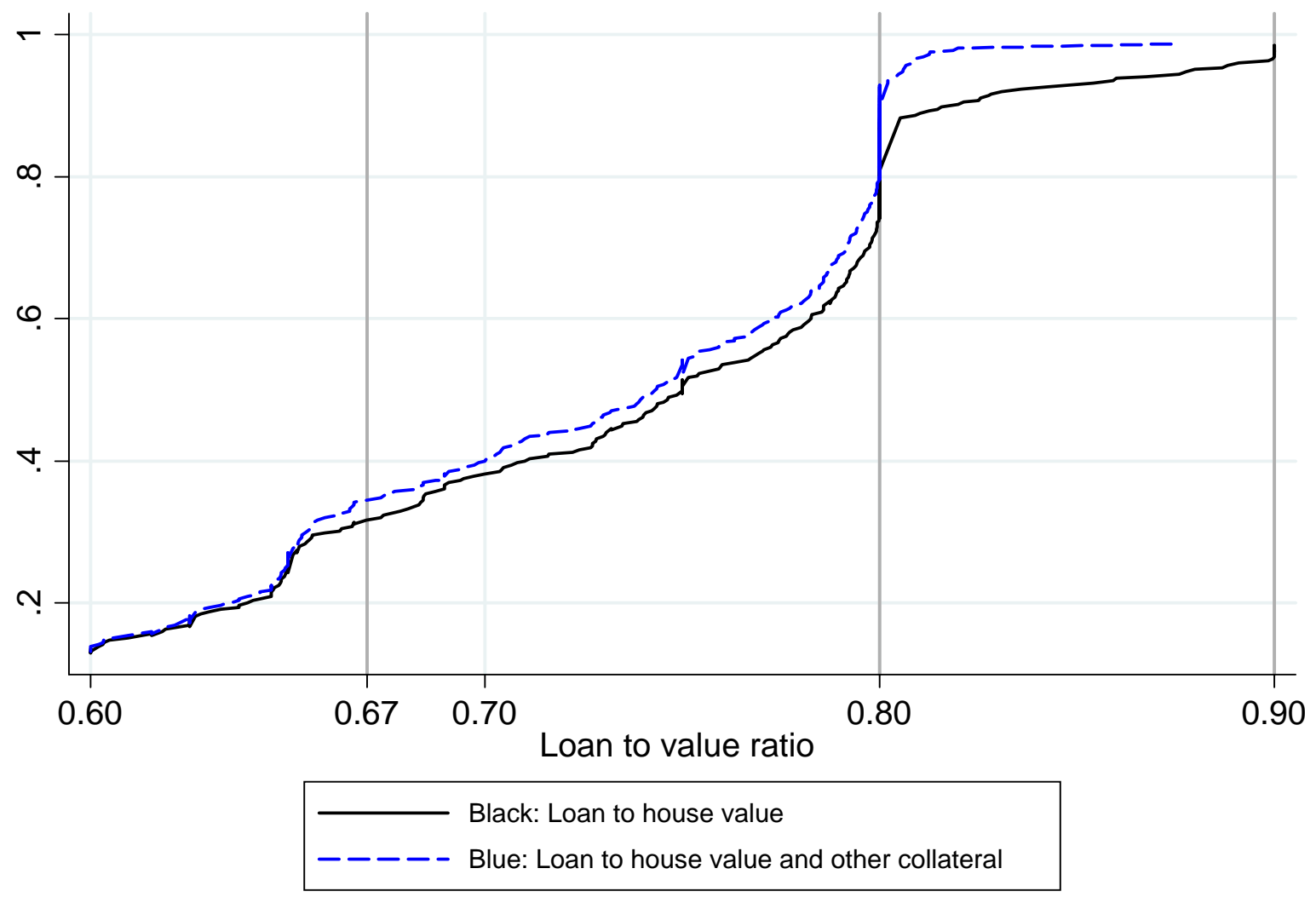


Table 4. Characteristics of applications with high vs. low LTV ratios

This table shows the share of free liquid assets over total mortgage value of more than $10 \%$ (first row), the share of free liquid and illiquid assets over total mortgage value of more than 10\% (second row) depending on whether the LTV ratio is above or below 80\% (Panel A). Panel B shows the share of mortgage tranches with maturities of 5 years or less depending on the LTV ratio for households with free liquid assets of only up to $10 \%$. The sample consists of first-time mortgage applications from September 2012 until January 2014. The last column tests the differences using univariate t-tests. Definitions of the variables are provided in appendix $1 . * * *, * *, *$ denote statistical significance at the $0.01,0.05$ and 0.10 -level respectively.

\section{Panel A. Free (liquid or total) assets over total loan amount}

\begin{tabular}{l|c|c|c}
\hline \hline Variable & LTV $>\mathbf{8 0} \%$ & LTV <= 80\% & Difference \\
\hline Free liquid assets / loan amount $>\mathbf{1 0} \%$ & $\begin{array}{c}0.183 \\
(\mathrm{~N}=82)\end{array}$ & $\begin{array}{c}0.362 \\
(\mathrm{~N}=243)\end{array}$ & $\begin{array}{c}-0.179 * * * \\
(0.059) \\
(\mathrm{N}=325)\end{array}$ \\
\hline Free liquid and illiquid assets / loan amount $>\mathbf{1 0} \%$ & $\begin{array}{c}0.537 \\
(\mathrm{~N}=82)\end{array}$ & $\begin{array}{c}0.790 \\
(\mathrm{~N}=243)\end{array}$ & $\begin{array}{c}-0.253^{* * *} \\
(0.055) \\
(\mathrm{N}=325)\end{array}$ \\
\hline \hline
\end{tabular}

Panel B. Share of short-term tranches (Households with free liquid assets $<=10 \%$ only)

\begin{tabular}{l|c|c|c} 
Panel B. Share of short-term tranches (Households with free liquid assets <= $\mathbf{1 0} \%$ only) \\
\hline Variable & $\mathbf{L T V}>\mathbf{8 0} \%$ & $\mathbf{L T V}<=\mathbf{8 0 \%}$ & Difference \\
\hline Share of tranches with maturity of 5 years or less & $\begin{array}{c}0.308 \\
(\mathrm{~N}=67)\end{array}$ & $\begin{array}{c}0.363 \\
(\mathrm{~N}=155)\end{array}$ & $\begin{array}{c}-0.055 \\
(0.054) \\
(\mathrm{N}=222)\end{array}$ \\
\hline \hline
\end{tabular}


Table 5. Characteristics of households taking risky mortgages

This table shows the results of linear regressions where the dependent variables indicate the mortgage share with variable interest rate (columns 1-4), the mortgage share with a maturity of five years or less (columns 5-8). All regressions include advisor dummy variables, quarterly time dummy variables and household control variables. Regressions reported in columns 4 \& 8 include MS Region fixed effects. D.Price (2003-2012) (Ln) is the natural logarithm of D.Price (2003-2012). Price to rent ratio (2012) (Ln) is the natural logarithm of Price to rent ratio (2012). Household control variables are Fix wage income (Ln), Self-employed, Bonus payment, Liquid assets (Ln), Illiquid assets (Ln), Male, Age below 35, Age between 35 and 40, Married, Other real estate, Debt. Definitions of the variables are provided in appendix 1. Standard errors are clustered on the MS Region level and reported in parentheses. ${ }^{* * *}, * * *$ denote statistical significance at the $0.01,0.05$ and 0.10 -level, respectively.

\begin{tabular}{|c|c|c|c|c|c|c|c|c|}
\hline $\begin{array}{r}\text { Sample } \\
\text { Dependent variable }\end{array}$ & \multicolumn{4}{|c|}{$\begin{array}{l}\text { First-time mortgage applications } \\
\text { Share with variable interest rate }\end{array}$} & \multicolumn{4}{|c|}{$\begin{array}{l}\text { First-time mortgage applications } \\
\text { Share with maturity <=5 years }\end{array}$} \\
\hline Expected interest increase & $\begin{array}{c}0.016 \\
{[0.048]} \\
\end{array}$ & $\begin{array}{c}-0.035 \\
{[0.046]} \\
\end{array}$ & $\begin{array}{c}-0.038 \\
{[0.045]} \\
\end{array}$ & $\begin{array}{c}0.000 \\
{[0.064]}\end{array}$ & $\begin{array}{c}-0.057 \\
{[0.059]}\end{array}$ & $\begin{array}{c}-0.094 * * \\
{[0.044]} \\
\end{array}$ & $\begin{array}{c}-0.096 * * \\
{[0.044]} \\
\end{array}$ & $\begin{array}{c}-0.066 \\
{[0.066]}\end{array}$ \\
\hline $\begin{array}{l}\text { D.Price (2003-2012) (Ln) } \\
\text { Price to rent ratio (2012) (Ln) }\end{array}$ & & $\begin{array}{c}0.064 \\
{[0.046]}\end{array}$ & $\begin{array}{c}0.393 \\
{[0.262]} \\
\end{array}$ & & & $\begin{array}{c}0.104^{* *} \\
{[0.047]}\end{array}$ & $\begin{array}{l}0.561 * * \\
{[0.228]}\end{array}$ & \\
\hline Risk averse & $\begin{array}{c}0.027 \\
{[0.059]}\end{array}$ & $\begin{array}{l}1.148 * \\
{[0.642]}\end{array}$ & $\begin{array}{c}1.984 \\
{[1.208]} \\
\end{array}$ & $\begin{array}{c}0.030 \\
{[0.061]} \\
\end{array}$ & $\begin{array}{c}0.003 \\
{[0.057]} \\
\end{array}$ & $\begin{array}{l}1.686 * \\
{[0.922]} \\
\end{array}$ & $\begin{array}{l}2.932 * * \\
{[1.301]}\end{array}$ & $\begin{array}{c}-0.009 \\
{[0.051]}\end{array}$ \\
\hline $\begin{array}{l}\text { Expected interest increase* } \\
\text { Risk averse } \\
\text { D.Price (2003-2012) (Ln)* } \\
\text { Risk averse } \\
\text { Price to rent ratio (2012) (Ln)* } \\
\text { Risk averse }\end{array}$ & $\begin{array}{l}-0.137 * \\
{[0.077]}\end{array}$ & $\begin{array}{l}-0.095 * \\
{[0.053]}\end{array}$ & $\begin{array}{l}-0.530 \\
{[0.323]}\end{array}$ & $\begin{array}{c}-0.142 \\
{[0.097]}\end{array}$ & $\begin{array}{l}-0.077 \\
{[0.099]}\end{array}$ & $\begin{array}{l}-0.141^{*} \\
{[0.076]}\end{array}$ & $\begin{array}{c}-0.786 * * \\
{[0.347]}\end{array}$ & $\begin{array}{l}-0.113 \\
{[0.099]}\end{array}$ \\
\hline Household control variables & YES & YES & YES & YES & YES & YES & YES & YES \\
\hline MS Region FE & $\mathrm{NO}$ & $\mathrm{NO}$ & $\mathrm{NO}$ & YES & $\mathrm{NO}$ & $\mathrm{NO}$ & $\mathrm{NO}$ & YES \\
\hline Quarterly time dummy & YES & YES & YES & YES & YES & YES & YES & YES \\
\hline Advisor dummy & YES & YES & YES & YES & YES & YES & YES & YES \\
\hline Observations & 295 & 295 & 295 & 295 & 295 & 295 & 295 & 295 \\
\hline R-squared & 0.273 & 0.274 & 0.278 & 0.297 & 0.266 & 0.277 & 0.283 & 0.309 \\
\hline $\begin{array}{l}\text { Standard errors clustered } \\
\text { Method }\end{array}$ & $\begin{array}{l}\text { MS Region } \\
\text { OLS } \\
0.26\end{array}$ & $\begin{array}{l}\text { MS Region } \\
\text { OLS } \\
0.26\end{array}$ & $\begin{array}{l}\text { MS Region } \\
\text { OLS } \\
0.26\end{array}$ & $\begin{array}{l}\text { MS Region } \\
\text { OLS } \\
0.26\end{array}$ & $\begin{array}{l}\text { MS Region } \\
\text { OLS } \\
0.38\end{array}$ & $\begin{array}{l}\text { MS Region } \\
\text { OLS } \\
0.38\end{array}$ & $\begin{array}{l}\text { MS Region } \\
\text { OLS } \\
0.38\end{array}$ & $\begin{array}{l}\text { MS Region } \\
\text { OLS } \\
0.38\end{array}$ \\
\hline
\end{tabular}




\begin{tabular}{|c|c|}
\hline Variable name & Definition \\
\hline \multicolumn{2}{|l|}{ Household characteristics } \\
\hline Male & Dummy $=1$ if the credit applicant is male, $=0$ otherwise. \\
\hline Age & Age of the main credit applicant in years. \\
\hline Married & Dummy = 1 if the credit applicant is married, = 0 otherwise. \\
\hline Expected interest increase & Dummy = 1 if the credit applicant expects an interest rate increase, $=0$ otherwise. \\
\hline Risk averse & $\begin{array}{l}\text { Dummy }=1 \text { if the credit applicant has low risk tolerance ( } 0 \text { or } 1 \text { on a self-reported scale } \\
\text { that ranges from } 0 \text { to } 4 \text { ), = } 0 \text { otherwise. }\end{array}$ \\
\hline City residence & $\begin{array}{l}\text { Dummy = } 1 \text { if the credit applicant lives in an urban agglomeration (based on the } \\
\text { definition used in the Federal Population Census 2000). }\end{array}$ \\
\hline \multicolumn{2}{|l|}{ Financial wealth } \\
\hline Total assets & All liquid and illiquid financial assets. \\
\hline Liquid assets & Liquid financial assets (cash, deposits, securities etc.). \\
\hline Illiquid assets & Illiquid financial assets (second pillar, third pillar, life insurance etc.). \\
\hline Free liquid assets & Liquid financial assets not employed as equity or collateral for the property purchase. \\
\hline Free liquid \& illiquid assets & Liquid \& illiquid financial assets not employed as equity or collateral for the property pur \\
\hline Other collateral & Financial assets pledged as collateral (except property value). \\
\hline Other real estate & Dummy $=1$ if the credit applicant owns other real estate, $=0$ otherwise. \\
\hline Debt & $\begin{array}{l}\text { Dummy }=1 \text { if the credit applicant's annual debt service (for other obligations than the } \\
\text { mortgage) is above } 10 \% \text { of the fix wage income, }=0 \text { otherwise. }\end{array}$ \\
\hline \multicolumn{2}{|r|}{ 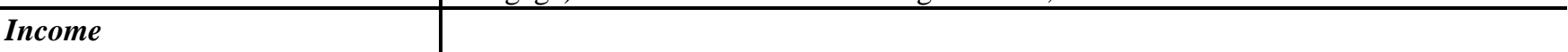 } \\
\hline Total household income & Household income in CHF per year (before taxes). \\
\hline Fix wage income & Household wage income in CHF per year (before taxes). \\
\hline Main fix wage income & The main household wage income in CHF per year (before taxes). \\
\hline Self-employed & Dummy $=1$ if the credit applicant is self-employed, $=0$ otherwise. \\
\hline Bonus payment & Annual bonus payment as a share of fix wage income per year. \\
\hline \multicolumn{2}{|l|}{ Mortgage } \\
\hline Total loan amount & Total mortgage loan (fixed and variable tranches) in CHF. \\
\hline Share with fixed interest rate & Fixed interest rate mortgage tranches over total loan amount. \\
\hline Share with variable interest rate & Variable interest rate mortgage tranches over total loan amount. \\
\hline $\begin{array}{l}\text { Share with fixed interest rate }<=5 \\
\text { years }\end{array}$ & Fixed interest rate mortgage with maturity $<=5$ years over total loan amount. \\
\hline Share with maturity $>5$ years & Mortgage tranches with maturity $>5$ years over total loan amount. \\
\hline Share with maturity $<=5$ years & Mortgage tranches with maturity $<=5$ years over total loan amount. \\
\hline Number of tranches & Number of mortgage tranches per application. \\
\hline \multicolumn{2}{|l|}{ Property } \\
\hline Property reference value & Property value in CHF as published or demanded by the seller. \\
\hline Property hedonic value & Property value in CHF as assessed by an internal hedonic pricing method. \\
\hline D.Price (2003-2012) & The change of house prices per MS Region between 2003 and 2012. \\
\hline Price to rent ratio (2012) & The ratio of house prices to rental rate per MS Region in 2012. \\
\hline
\end{tabular}




\section{Appendix 2. Descriptive statistics}

Definitions of the variables are provided in appendix 1.

\begin{tabular}{|c|c|c|c|c|c|c|c|}
\hline & Mean & Min & $\begin{array}{r}0.25 \\
\text { percentile }\end{array}$ & $\begin{array}{r}0.50 \\
\text { percentile }\end{array}$ & $\begin{array}{r}0.75 \\
\text { percentile }\end{array}$ & Max & Obs \\
\hline \multicolumn{8}{|l|}{ Household characteristics } \\
\hline Male & 0.79 & 0 & 1 & 1 & 1 & 1 & 325 \\
\hline Age & 41.00 & 24 & 34 & 39 & 46 & 78 & 325 \\
\hline Married & 0.62 & 0 & 0 & 1 & 1 & 1 & 325 \\
\hline Expected interest increase & 0.27 & 0 & 0 & 0 & 1 & 1 & 325 \\
\hline Risk averse & 0.36 & 0 & 0 & 0 & 1 & 1 & 325 \\
\hline City residence & 0.89 & 0 & 1 & 1 & 1 & 1 & 325 \\
\hline \multicolumn{8}{|l|}{ Financial wealth } \\
\hline Total assets & 646'922 & 59'314 & $282 ' 500$ & $475 ' 123$ & $815^{\prime} 158$ & $4^{\prime} 256^{\prime} 000$ & 325 \\
\hline Liquid assets & 376 & 21 & 143 & 270 & 474 & 3'900 & 325 \\
\hline Illiquid assets & $270 ' 663$ & 0 & $59 ' 671$ & 172'286 & $337 ' 346$ & 2'907'089 & 325 \\
\hline Free liquid assets & $114 ' 690$ & 0 & 0 & 6'000 & $107 ' 100$ & 3'541'000 & 325 \\
\hline Free liquid \& illiquid assets & $337 ' 926$ & 0 & $56 ' 000$ & 173'129 & $428^{\prime} 716$ & 3'897'000 & 325 \\
\hline Other collateral & 13'374 & 0 & 0 & 0 & 0 & 687'044 & 325 \\
\hline Other real estate & 0.04 & 0 & 0 & 0 & 0 & 1 & 325 \\
\hline Debt & 0.15 & 0 & 0 & 0 & 0 & 1 & 325 \\
\hline \multicolumn{8}{|l|}{ Income } \\
\hline Total household income & $217 ' 629$ & $35 ' 409$ & 140'950 & $185 ' 800$ & $250 ' 000$ & 1'144'500 & 325 \\
\hline Fix wage income & 193'975 & 34 '989 & $131 ' 508$ & $168 ' 800$ & $224 ' 000$ & 784'500 & 325 \\
\hline Main fix wage income & 149'638 & 0 & 97'500 & $126 ' 479$ & $166^{\prime} 908$ & 768'000 & 325 \\
\hline Self-employed & 0.07 & 0 & 0 & 0 & 0 & 1 & 325 \\
\hline Bonus payment & 0.05 & 0.00 & 0.00 & 0.00 & 0.06 & 0.79 & 325 \\
\hline \multicolumn{8}{|l|}{ Mortgage } \\
\hline Total loan amount & 731'204 & $126^{\prime} 000$ & $500 ' 000$ & $662 ' 000$ & $872 ' 000$ & 2'880'000 & 325 \\
\hline Share with fixed interest rate & 0.74 & 0.00 & 0.55 & 1.00 & 1.00 & 1.00 & 325 \\
\hline Share with variable interest rate & 0.26 & 0.00 & 0.00 & 0.00 & 0.45 & 1.00 & 325 \\
\hline $\begin{array}{l}\text { Share with fixed interest rate } \\
<=5 \text { years }\end{array}$ & 0.12 & 0.00 & 0.00 & 0.00 & 0.00 & 1.00 & 325 \\
\hline Share with maturity $>5$ years & 0.63 & 0.00 & 0.43 & 0.68 & 1.00 & 1.00 & 325 \\
\hline Share with maturity $<=5$ years & 0.37 & 0.00 & 0.00 & 0.32 & 0.57 & 1.00 & 325 \\
\hline Number of tranches & 1.74 & 1.00 & 1.00 & 2.00 & 2.00 & 4.00 & 325 \\
\hline \multicolumn{8}{|l|}{ Property } \\
\hline Property reference value & 1'028'157 & $176^{\prime} 000$ & 720'000 & $920{ }^{\prime} 000$ & 1'250'000 & 3'600'000 & 325 \\
\hline Property hedonic value & 1'095'311 & 0 & $762^{\prime} 000$ & 979'000 & 1'303'000 & 4'301'000 & 315 \\
\hline D.Price (2003-2012) & 8.72 & 1.06 & 5.74 & 8.52 & 11.27 & 21.26 & 325 \\
\hline Price to rent ratio (2012) & 43.15 & 32.24 & 38.28 & 42.38 & 47.63 & 55.04 & 325 \\
\hline
\end{tabular}




\section{Appendix 3. Regional distributions}

Panel A. First-time mortgage applications by residency of the mortgage applicant (per MS Region)

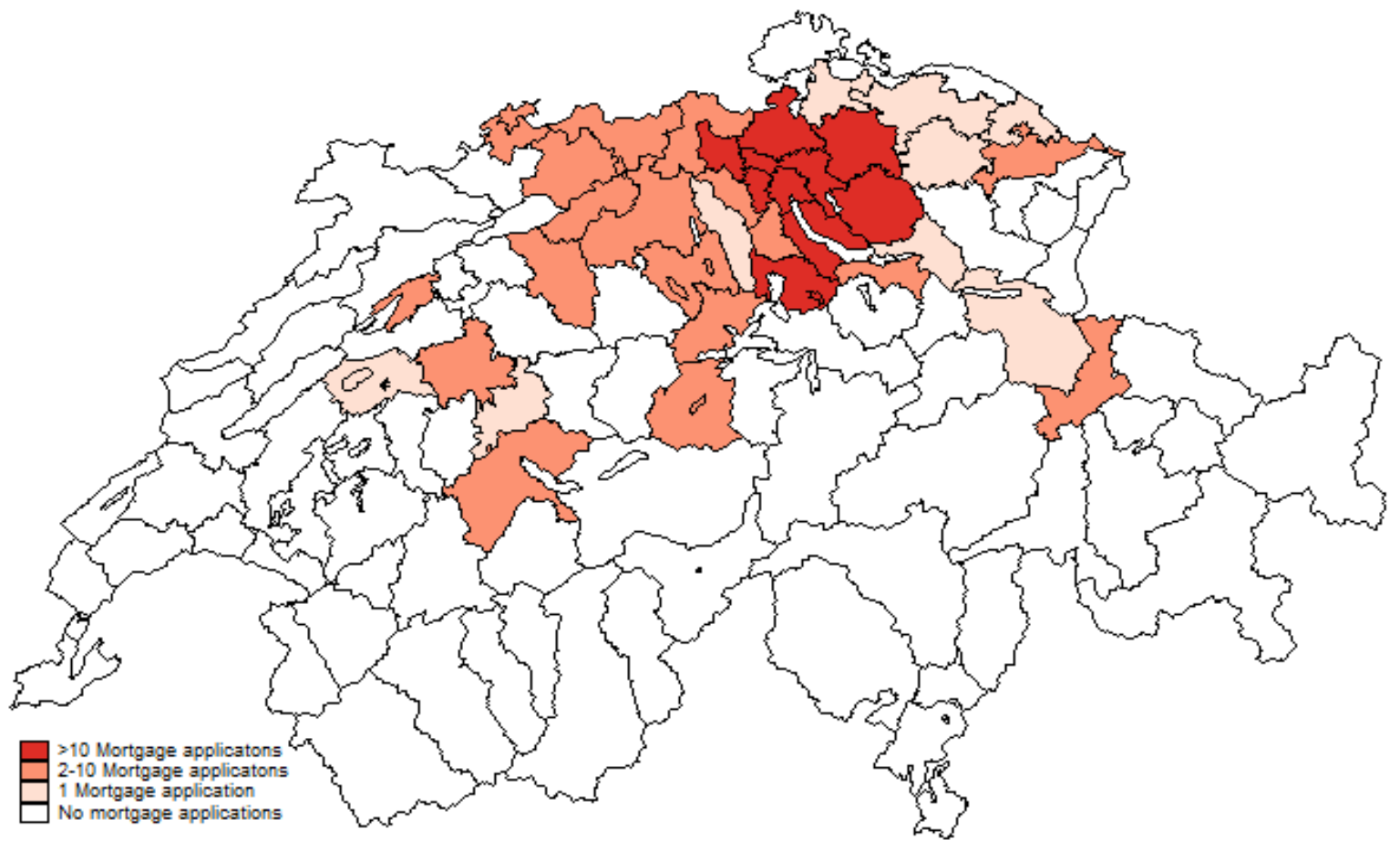

Panel B. Price-to-rent ratios in 2012 by location of the property (per MS Region)

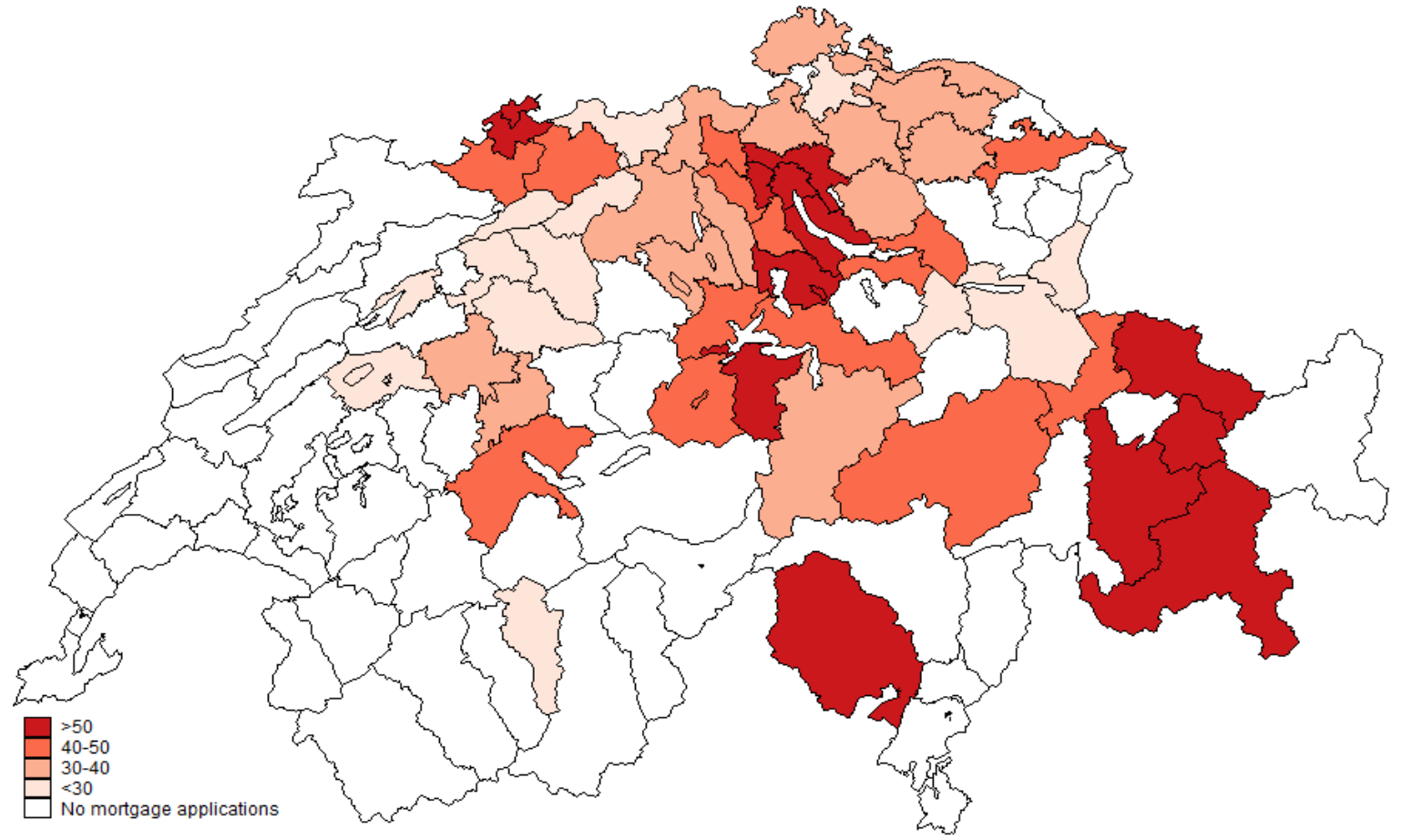


Panel C. D.Price (2003-2012) by location of the property (per MS Region)

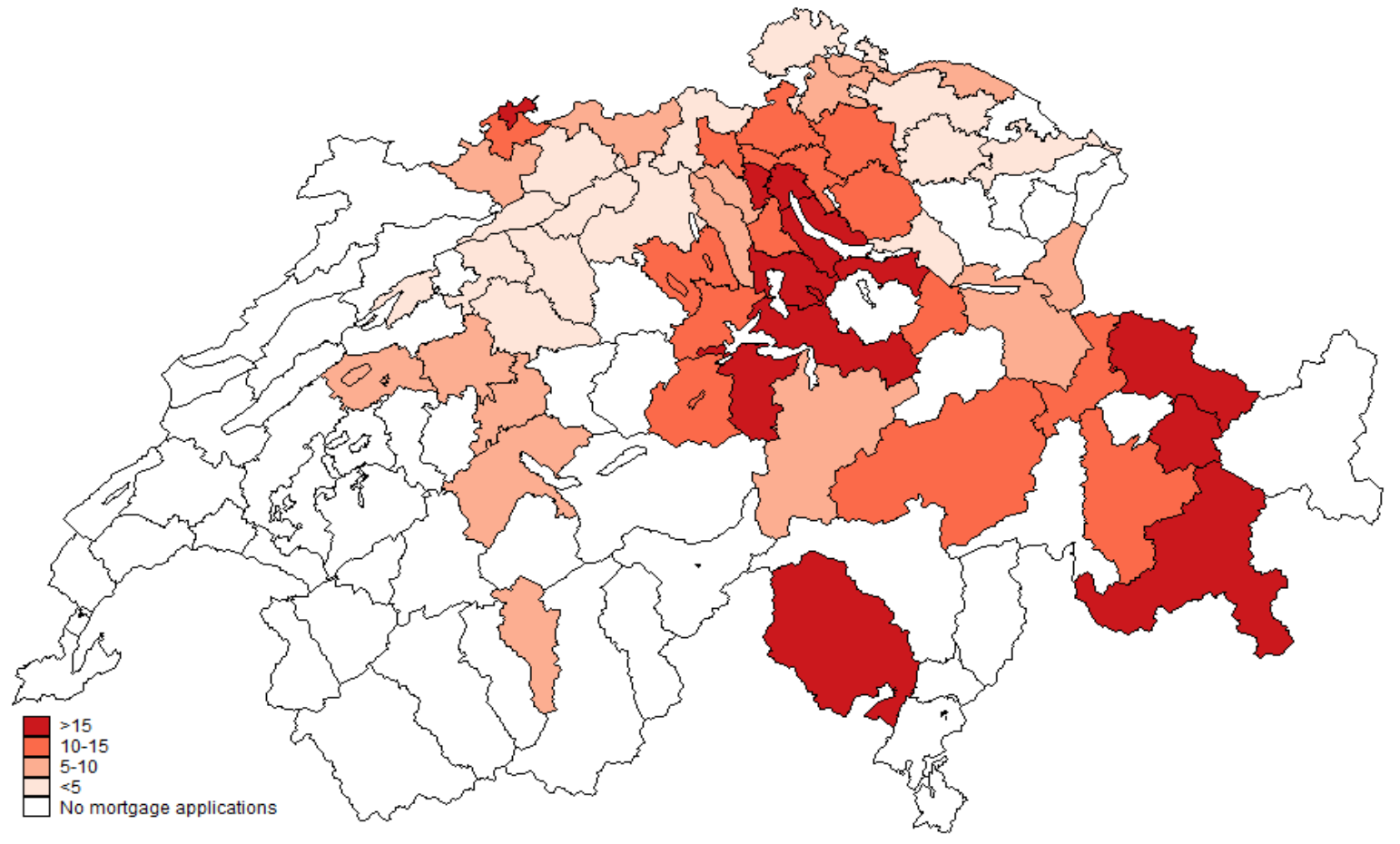


Appendix 4. Historical house prices 1985 - 2009

This figure displays the level of house prices for single family houses and condominiums in Switzerland between 1985 and 2009. The index for both types of housing are set at 100 in the year 2000.

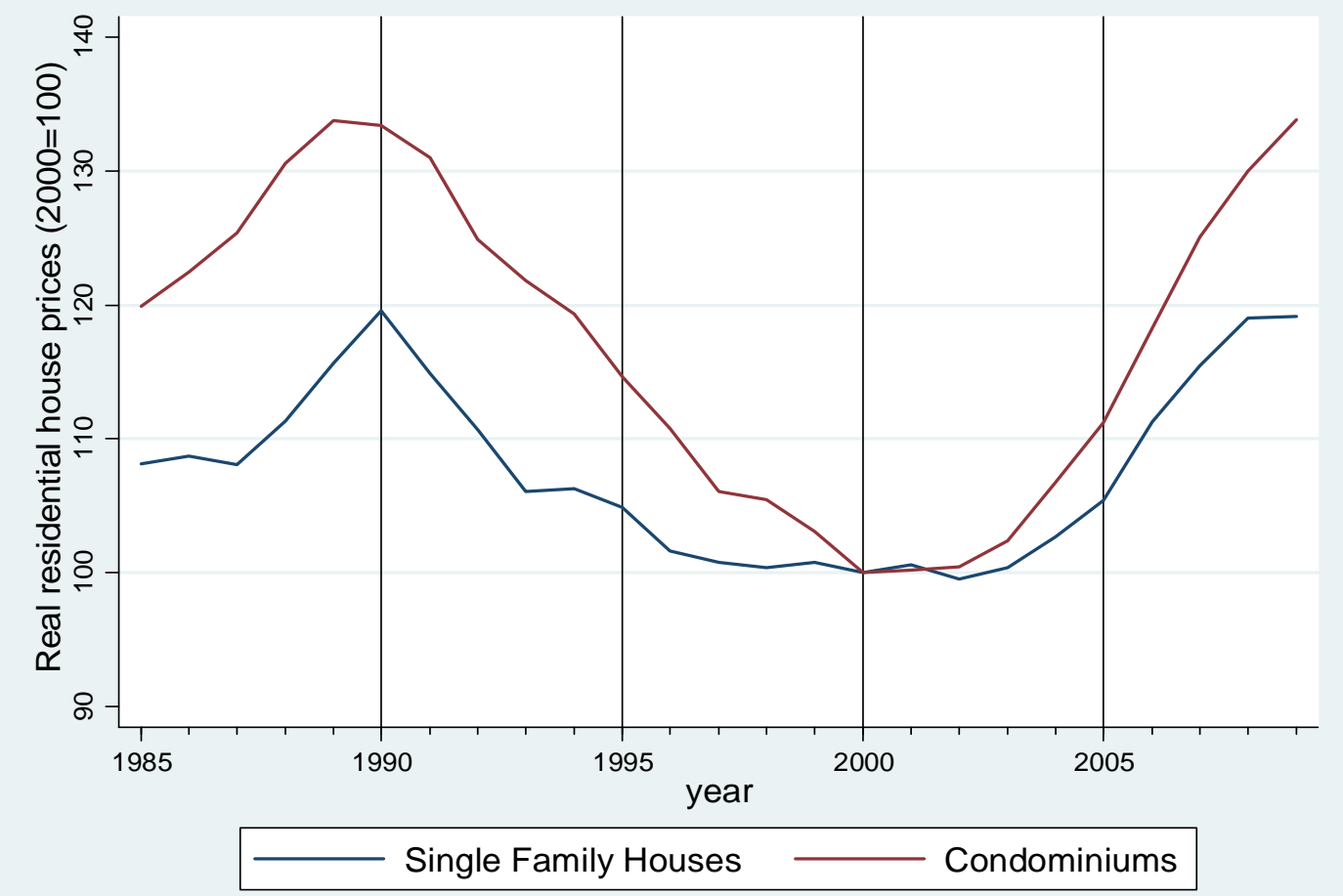

Source: AREGGER, BROWN, and ROSSI (2013) 


\section{Appendix 5. Cumulative distribution of loan to value ratios (different interest rates)}

This figure shows cumulative distributions of payment to income ratios (PTI) for 325 first-time mortgage applications from September 2012 until January 2014. The solid black indicates the PTI using a calculatory installment rate of $4 \%$ on the loan amount (3\% interest and $1 \%$ amortization) and $1 \%$ upkeep on the property reference value as a share of fix wage income. The dashed blue line indicates the PTI using a calculatory installment rate of $5 \%$ on the loan amount (4\% interest and $1 \%$ amortization) and $1 \%$ upkeep on the property reference value as a share of fix wage income. The dotted red line indicates the PTI using a calculatory installment rate of $6 \%$ on the loan amount (5\% interest and $1 \%$ amortization) and $1 \%$ upkeep on the property reference value as a share of fix wage income. The dotted orange line indicates the PTI using a calculatory installment rate of 7\% on the loan amount (6\% interest and 1\% amortization) and 1\% upkeep on the property reference value as a share of fix wage income. Definitions of the variables are provided in appendix 1.

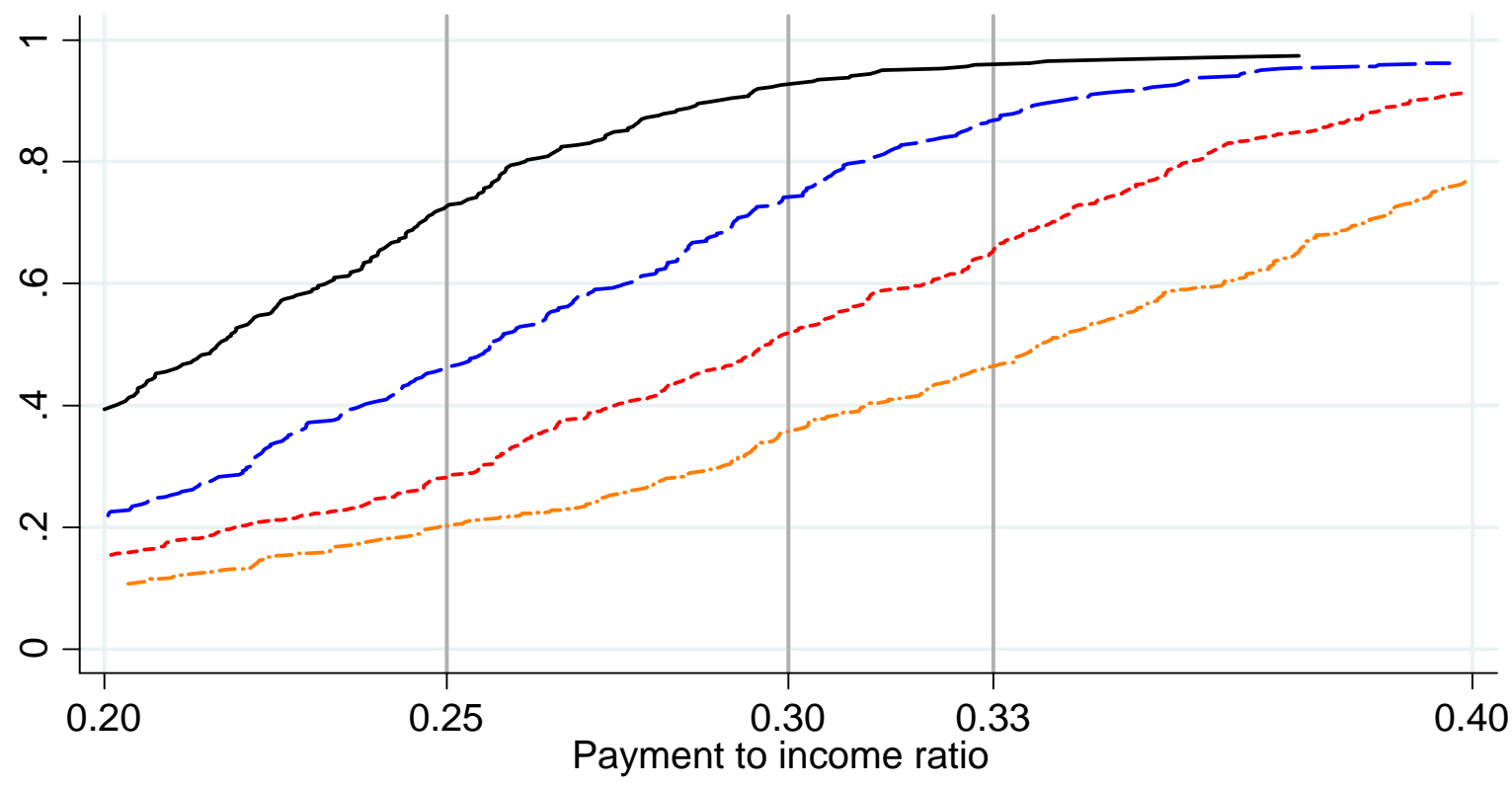

$$
\begin{aligned}
& \text { Black: } 3 \% \text { interest plus 1\% amortization plus 1\% upkeep over fix wage income } \\
& \text { - - Blue: } 4 \% \text { interest plus } 1 \% \text { amortization plus } 1 \% \text { upkeep over fix wage income } \\
& \text {------ Red: } 5 \% \text { interest plus 1\% amortization plus } 1 \% \text { upkeep over fix wage income } \\
& \text {-.-.-... Orange: } 6 \% \text { interest plus } 1 \% \text { amortization plus } 1 \% \text { upkeep over fix wage income }
\end{aligned}
$$


This table shows the mean share of first-time mortgage applicants asking for a variable interest mortgage and fixed interest mortgage (maturity not more than 5 years) depending on whether the payment to income ratio is above or below $30 \%$. The last column tests the differences using univariate t-tests. The payment to income ratio is calculated using a calculatory interest rate of $6 \%$ on the total loan amount and $1 \%$ upkeep on the property reference value over fix wage income (Panel A), a calculatory interest rate of $6 \%$ on the total loan amount and $1 \%$ upkeep on the property reference value over total income (Panel B). Definitions of the variables are provided in appendix 1. ***, **, * denote statistical significance at the $0.01,0.05$ and 0.10 -level respectively.

Panel A. PTI calculated using $6 \%$ plus $1 \%$ for upkeep over fix wage income

\begin{tabular}{l|c|c|c}
\hline \hline Variable & PTI $>\mathbf{3 0 \%}$ & PTI $<=\mathbf{3 0 \%}$ & Difference \\
\hline $\begin{array}{l}\text { Share with variable interest rate or } \\
\text { with fixed interest rate }<=5 \text { years }\end{array}$ & $\begin{array}{c}0.388 \\
(\mathrm{~N}=157)\end{array}$ & $\begin{array}{c}0.368 \\
(\mathrm{~N}=168)\end{array}$ & $\begin{array}{c}0.020 \\
(0.042) \\
(\mathrm{N}=325)\end{array}$ \\
\hline \hline
\end{tabular}

Panel B. PTI calculated using $6 \%$ plus $1 \%$ for upkeep over total income

\begin{tabular}{l|c|c|c}
\hline \hline Variable & PTI $>\mathbf{3 0 \%}$ & PTI <=30\% & Difference \\
\hline $\begin{array}{l}\text { Share with variable interest rate or } \\
\text { with fixed interest rate }<=5 \text { years }\end{array}$ & $\begin{array}{c}0.363 \\
(\mathrm{~N}=121)\end{array}$ & $\begin{array}{c}0.386 \\
(\mathrm{~N}=204)\end{array}$ & $\begin{array}{c}-0.024 \\
(0.043) \\
(\mathrm{N}=325)\end{array}$ \\
\hline \hline
\end{tabular}


This table shows the share of free liquid assets over total mortgage value of more than $10 \%$ (first row), the share of free liquid and illiquid assets over total mortgage value of more than 10\% (second row) depending on whether the LTV ratio is above or below 70\% (Panel A). In Panel B, this table shows the share of mortgage tranches with maturities of 5 years or less depending on the LTV ratio and the ratio of free liquid assets over total loan amount. The sample consists of firsttime mortgage applications from September 2012 until January 2014. The last column tests the differences using univariate t-tests. Definitions of the variables are provided in appendix 1. ***,**, * denote statistical significance at the $0.01,0.05$ and 0.10 -level respectively.

Panel A. Free (liquid or total) assets over total loan amount

\begin{tabular}{l|c|c|c}
\hline \hline Variable & LTV > 70\% & LTV <= 70\% & Difference \\
\hline Free liquid assets / loan amount $>\mathbf{1 0 \%}$ & $\begin{array}{c}0.234 \\
(\mathrm{~N}=201)\end{array}$ & $\begin{array}{c}0.452 \\
(\mathrm{~N}=124)\end{array}$ & $\begin{array}{c}-0.218^{* * *} \\
(0.052) \\
(\mathrm{N}=325)\end{array}$ \\
\hline $\begin{array}{l}\text { Free liquid and illiquid assets / loan } \\
\text { amount }>\mathbf{1 0} \%\end{array}$ & $\begin{array}{c}0.622 \\
(\mathrm{~N}=201)\end{array}$ & $\begin{array}{c}0.895 \\
(\mathrm{~N}=124)\end{array}$ & $\begin{array}{c}-0.273^{* * *} \\
(0.049) \\
(\mathrm{N}=325)\end{array}$ \\
\hline \hline
\end{tabular}

Panel B. Share of short-term tranches (Households with free liquid assets $<=10 \%$ only)

\begin{tabular}{l|c|c|c}
\hline \hline Variable & LTV $>\mathbf{7 0 \%}$ & LTV <= 70\% & Difference \\
\hline $\begin{array}{l}\text { Share of tranches with maturity of } 5 \\
\text { years or less }\end{array}$ & $\begin{array}{c}0.310 \\
(\mathrm{~N}=154)\end{array}$ & $\begin{array}{c}0.428 \\
(\mathrm{~N}=68)\end{array}$ & $\begin{array}{c}-0.117^{*} \\
(0.054) \\
(\mathrm{N}=222)\end{array}$ \\
\hline \hline
\end{tabular}


This table shows the share of free liquid assets over total mortgage value of more than 10\% (first row), the share of free liquid and illiquid assets over total mortgage value of more than 10\% (second row) depending on whether the LTV ratio is above or below 80\% (Panel A). The sample consists of first-time mortgage applications from September 2012 until January 2014 with properties located in high price regions (above the median of price-to-rent ratio). The last column tests the differences using univariate t-tests. Definitions of the variables are provided in appendix 1 . ***, **, $*$ denote statistical significance at the $0.01,0.05$ and 0.10 -level respectively.

Panel A. Free (liquid or total) assets over total loan amount

\begin{tabular}{l|c|c|c}
\hline \hline Variable & LTV $>\mathbf{8 0} \%$ & LTV <= 80\% & Difference \\
\hline Free liquid assets / loan amount $>\mathbf{1 0} \%$ & $\begin{array}{c}0.231 \\
(\mathrm{~N}=39)\end{array}$ & $\begin{array}{c}0.355 \\
(\mathrm{~N}=124)\end{array}$ & $\begin{array}{c}-0.124 \\
(0.086) \\
(\mathrm{N}=163)\end{array}$ \\
\hline $\begin{array}{l}\text { Free liquid and illiquid assets / loan } \\
\text { amount }>\mathbf{1 0 \%}\end{array}$ & $\begin{array}{c}0.641 \\
(\mathrm{~N}=39)\end{array}$ & $\begin{array}{c}0.790 \\
(\mathrm{~N}=124)\end{array}$ & $\begin{array}{c}(0.149 * \\
(\mathrm{N}=163)\end{array}$ \\
\hline \hline
\end{tabular}




\section{Appendix 9. Missing values}

This table compares key socio-economic and mortgage characteristics of applications depending on whether the observations are included in the regressions in table 5 (column 2) or not included (column 3). The last column tests the differences using univariate t-tests. Definitions of the variables are provided in appendix $1 .{ }^{* *}$, **, * denote statistical significance at the $0.01,0.05$ and 0.10 -level respectively.

\begin{tabular}{|c|c|c|c|}
\hline Variable & $\begin{array}{l}\text { Observations included } \\
\text { in the regression }\end{array}$ & $\begin{array}{l}\text { Observations not included } \\
\text { in the regression }\end{array}$ & Difference \\
\hline Age & $\begin{array}{c}40.854 \\
(\mathrm{~N}=295)\end{array}$ & $\begin{array}{l}42.433 \\
(\mathrm{~N}=30)\end{array}$ & $\begin{array}{c}-1.579 \\
(1.863) \\
(\mathrm{N}=325)\end{array}$ \\
\hline City residence & $\begin{array}{c}0.264 \\
(\mathrm{~N}=295)\end{array}$ & $\begin{array}{c}0.300 \\
(\mathrm{~N}=30)\end{array}$ & $\begin{array}{c}-0.036 \\
(0.085) \\
(\mathrm{N}=325)\end{array}$ \\
\hline Married & $\begin{array}{c}0.617 \\
(\mathrm{~N}=295)\end{array}$ & $\begin{array}{c}0.633 \\
(\mathrm{~N}=30)\end{array}$ & $\begin{array}{c}-0.016 \\
(0.093) \\
(\mathrm{N}=325)\end{array}$ \\
\hline Fix wage income & $\begin{array}{l}194.586 \\
(\mathrm{~N}=295)\end{array}$ & $\begin{array}{l}187.972 \\
(\mathrm{~N}=30)\end{array}$ & $\begin{array}{c}6.614 \\
(19.743) \\
(\mathrm{N}=325) \\
\end{array}$ \\
\hline Total assets & $\begin{array}{l}639.151 \\
(\mathrm{~N}=295)\end{array}$ & $\begin{array}{l}723.340 \\
(\mathrm{~N}=30)\end{array}$ & $\begin{array}{c}-84.189 \\
(110.830) \\
(\mathrm{N}=325)\end{array}$ \\
\hline Total loan amount & $\begin{array}{l}733.184 \\
(\mathrm{~N}=295)\end{array}$ & $\begin{array}{l}711.736 \\
(\mathrm{~N}=30)\end{array}$ & $\begin{array}{c}21.448 \\
(73.641) \\
(\mathrm{N}=325)\end{array}$ \\
\hline Share with variable interest rate & $\begin{array}{c}0.261 \\
(\mathrm{~N}=295)\end{array}$ & $\begin{array}{c}0.260 \\
(\mathrm{~N}=30)\end{array}$ & $\begin{array}{c}0.001 \\
(0.064) \\
(\mathrm{N}=325)\end{array}$ \\
\hline Share with maturity $<=5$ years & $\begin{array}{c}0.376 \\
(\mathrm{~N}=295)\end{array}$ & $\begin{array}{c}0.362 \\
(\mathrm{~N}=30)\end{array}$ & $\begin{array}{c}0.014 \\
(0.073) \\
(\mathrm{N}=325) \\
\end{array}$ \\
\hline Property reference value & $\begin{array}{l}1031.496 \\
(\mathrm{~N}=295)\end{array}$ & $\begin{array}{l}995.325 \\
(\mathrm{~N}=30)\end{array}$ & $\begin{array}{c}36.171 \\
(94.977) \\
(\mathrm{N}=325)\end{array}$ \\
\hline
\end{tabular}

